\title{
The interactions of climate, spacing and genetics on clonal Eucalyptus plantations across Brazil and Uruguay
}

\author{
Dan Binkley $^{\mathrm{a}, \mathrm{b}, *}$, Otávio C. Campoe ${ }^{\mathrm{c}, \mathrm{f}}$, Clayton Alvares ${ }^{\mathrm{d}}$, Rafaela L. Carneiro ${ }^{\mathrm{d}}$, \\ Ítalo Cegatta ${ }^{\mathrm{d}}$, Jose Luiz Stape ${ }^{\mathrm{e}, \mathrm{f}}$ \\ a School of Forestry, Northern Arizona University, Flagstaff, AZ 86011, USA \\ b Department of Forest Ecology and Management, Swedish University of Agricultural Sciences, SE-901 83 Umeå, Sweden \\ ${ }^{c}$ Federal University of Santa Catarina - UFSC, 89.520-000 Curitibanos, SC, Brazil \\ d Instituto de Pesquisas e Estudos Florestais, Via Comendador Pedro Morganti, 3500 - Bairro Monte Alegre, Brazil \\ e Department of Forest Sciences, University of São Paulo, 13400 Piracicaba, SP, Brazil \\ ${ }^{\mathrm{f}}$ Department of Forest Science, São Paulo State University, 18600 Botucatu, SP, Brazil
}

\begin{abstract}
A B S T R A C T
Intensively managed plantations account for $1.5 \%$ of the world's forests, but they meet one-third of the demand for wood products. Eucalyptus plantations are among the most productive, with rates of growth depending heavily on genetics, silviculture, and climate. The TECHS Project examines productivity at 36 locations across a $3500 \mathrm{~km}$ gradient from Brazil to Uruguay, testing the interacting influences of genetics, temperature and precipitation on stemwood production. Across all sites and genotypes, stemwood production in the middle of the 6year rotation (the peak period of growth) averaged $22 \mathrm{Mg} \mathrm{ha}^{-1} \mathrm{yr}^{-1}$. Production varied by fivefold across sites, and by about 2-fold among genotypes within each site. The best clones at each location grew 1.5-4 $\mathrm{Mg} \mathrm{ha}^{-1} \mathrm{yr}^{-1}$ more than the average for all clones, underscoring the importance of matching genotypes to local site conditions. Contrary to patterns for natural forests across geographic gradients, Eucalyptus production declined with increasing temperature, dropping by $2.5 \mathrm{Mg} \mathrm{ha}^{-1} \mathrm{yr}^{-1}$ for a $1{ }^{\circ} \mathrm{C}$ temperature increase. The temperature effect was likely driven in part by the geographic covariance of temperature and rainfall, as rainfall tended to decline by $78 \mathrm{~mm} \mathrm{yr}^{-1}$ for each $1{ }^{\circ} \mathrm{C}$ increase in temperature. Stemwood production increased an average of $1.5 \mathrm{Mg} \mathrm{ha}^{-1} \mathrm{yr}^{-1}$ for each $100 \mathrm{~mm} \mathrm{yr}^{-1}$ increase in precipitation, but when the covariation of temperature and precipitation were included the apparent influence of precipitation declined to $0.4 \mathrm{Mg} \mathrm{ha}^{-1} \mathrm{yr}^{-1}$ for each $100 \mathrm{~mm} \mathrm{yr}^{-1}$ increase in precipitation. Future results will determine if within-site reductions in ambient rainfall have the same apparent influences as the rainfall pattern across the geographic gradient, as well as quantifying the importance of insects and pests in affecting growth. The supply of wood from intensively managed plantations will be strongly influenced by both temperature and precipitation at plantation locations, and with changing climates.
\end{abstract}

\section{Introduction}

Forests are a dominant vegetation type around most of the world, from frigid regions with very short growing seasons to the hottest tropical areas that have sufficient water supplies to support trees. We depend on forests for the production of fuel and wood products, and global consumption of wood products more than doubled from 1950 to 1990. Total global consumption of wood stabilized in about 1990 at a level of 3.5 billion $\mathrm{m}^{3} \mathrm{yr}^{-1}$, split about equally for fuel and for industrial products (Sutton, 2014). More than $80 \%$ of the world's wood supply was taken from natural forests in 1950, with planted forests supplying less than 20\% (Whiteman, 2014). The proportional contribution of wood supplied from natural forests has declined steadily to less than half the global demand in 2015, with actual harvest rates from natural forests declining since 1995 . This shift to reliance on planted forests to supply the demands for wood products resulted from increasing area devoted to planted forests (rising by 50\% from 1990 to 2015; Payn et al., 2015) combined with accelerating growth rates. Planted forests account for about 7\% of all forests (Whiteman, 2014). The most intensively managed, fast-growing plantations account for only $1.5 \%$ (54 million ha) of the world's forests, but they supply onethird of the non-fuelwood supply (INDUFOR, 2012). The most

\footnotetext{
* Corresponding author at: School of Forestry, Northern Arizona University, Flagstaff, AZ 86011, USA.

E-mail address: Dan.Binkley@alumni.ubc.ca.
} 
commonly planted species are pines in temperate and subtropical areas (Pinus, $42 \%$ of planted areas) and eucalypts (Eucalyptus $26 \%$ of planted areas) in subtropical and tropical areas.

The growth of forests varies across climatic gradients and species (Lieth and Whittaker, 1975, Roy et al., 2001), and plantations of suitable Eucalyptus species in the Tropical and Subtropical regions of Brazil are among the most productive forests in the world (Stape et al., 2010, Flores et al., 2016). Intensive research and development into forest growth resulted in a 4-fold increase in wood productivity in Brazil from 1970 to 2015 (Fig. 1). High rates of growth depend on application of results from research programs in genetic improvement (Resende et al., 2012) and silvicultural practices including site preparation, fertilization, spacing and weed control (Gonçalves et al., 2013). Climate strongly influences the growth of planted forests of Eucalyptus; a doubling of precipitation from $800 \mathrm{~mm} \mathrm{yr}^{-1}$ to $1600 \mathrm{~mm} \mathrm{yr}^{-1}$ along a 100$\mathrm{km}$ gradient in Bahia led to a 3-fold increase in wood growth (from $10 \mathrm{Mg} \mathrm{ha}^{-1} \mathrm{yr}^{-1}$ to $30 \mathrm{Mg} \mathrm{ha}^{-1} \mathrm{yr}^{-1}$; Stape et al., 2004). The addition of supplemental water within sites also increases Eucalyptus wood growth, by $20-80 \%$ (Stape et al., 2008; Ryan et al., 2010).

Sustaining or increasing the high rates of Eucalyptus growth will depend on a variety of changes in the future. Annual variations in precipitation can alter gross primary production and wood production by one-third to one-half (Stape et al., 2008), and any regional changes in climate would likely result in regional changes in production. Statistical and ecophysiological models that incorporate rainfall are commonly used to predict growth (Almeida et al., 2010; Scolforo et al., 2017). Short rotations (commonly about 6-8 years) allow land owners to change land use in responses to changing markets. Increases in the value of agricultural crops could lead to allocation of Eucalyptus forests to drier sites, which would require more specific genotypes and new management practices. Most intensively managed Eucalyptus plantations use genetically identical clonal trees within each stand to maximize uniformity and growth (Binkley et al., 2002; Stape et al., 2010), and genotypes differ substantially in rates of water use, the efficiency of wood production per unit of water transpired, and in responses to droughts (Hubbard et al., 2010, Blackman et al., 2017). Changes in silviculture could also be important, such as reducing the number of trees planted per hectare to reduce drought-related mortality (Hakamada et al., 2017). Besides these abiotic factors, exotic pests and diseases that harm Eucalyptus plantations have been increasingly reported in South America in the last decade with damages levels depending on genotypes and climate (Wingfield et al., 2013). Deployment of Eucalyptus clones requires many years of silvicultural evaluation (Resende et al., 2012). A long-standing goal of tree breeders and ecophysiologists is understanding the survival and growth of a large and diverse group of clones (derived from hybrids of various species) across large areas, and how this knowledge can be used to develop manageable ideotypes for tactical and operational decisions (Marcatti et al., 2017; Scolforo et al., 2017).

These impending changes in factors that drive the biological productivity of planted Eucalyptus forests led to the creation of an experimental research platform to investigate the influence of climate (water and thermal stresses), spacing and genetics on survival and growth at the level of individual trees and stands. The TECHS Project (Tolerance of Eucalyptus Clones to Hydric, Thermal and Biotic Stresses, www.ipef. br/techs/en) was launched in 2011 as a collaboration among people from 26 forest companies, 9 universities, and research institutions from Brazil, Uruguay, and the United States. The TECHS Project comprises 36 experimental sites across a $3500-\mathrm{km}$ gradient from the Amazon Region to Uruguay (Tables 1 and 2), examining:

1. How the growth of clonal Eucalyptus plantations relate to patterns in climate;

2. How production ecology factors (light and water use, efficiency of resource use, photosynthate allocation) account for the influence of climate;

3. The role of genotypes in determining growth responses to climate;

4. How spacing can mitigate drought effects, survival and growth at the scales of individual trees and plots of trees; and

5. How genotypes can be grouped into ideotypes regarding their ecophysiological responses to hydric and thermal stresses and susceptibility to pests and diseases for operational deployment.

This paper provides a description of the TECHS Project, and basic mid-rotation results for growth patterns and interactions between genetics and environmental conditions. A variety of detailed investigations will come from the Project in the next few years.

\section{Experimental design, site descriptions, and core measurements}

The core design for TECHS has 18 clones of Eucalyptus (Table 3), with 11 clones planted at each of 36 sites for a planned rotation length of 6 years (Figs. 2-4). Only 27 sites are included in this paper, as the others were planted later and had not reached the mid-rotation point
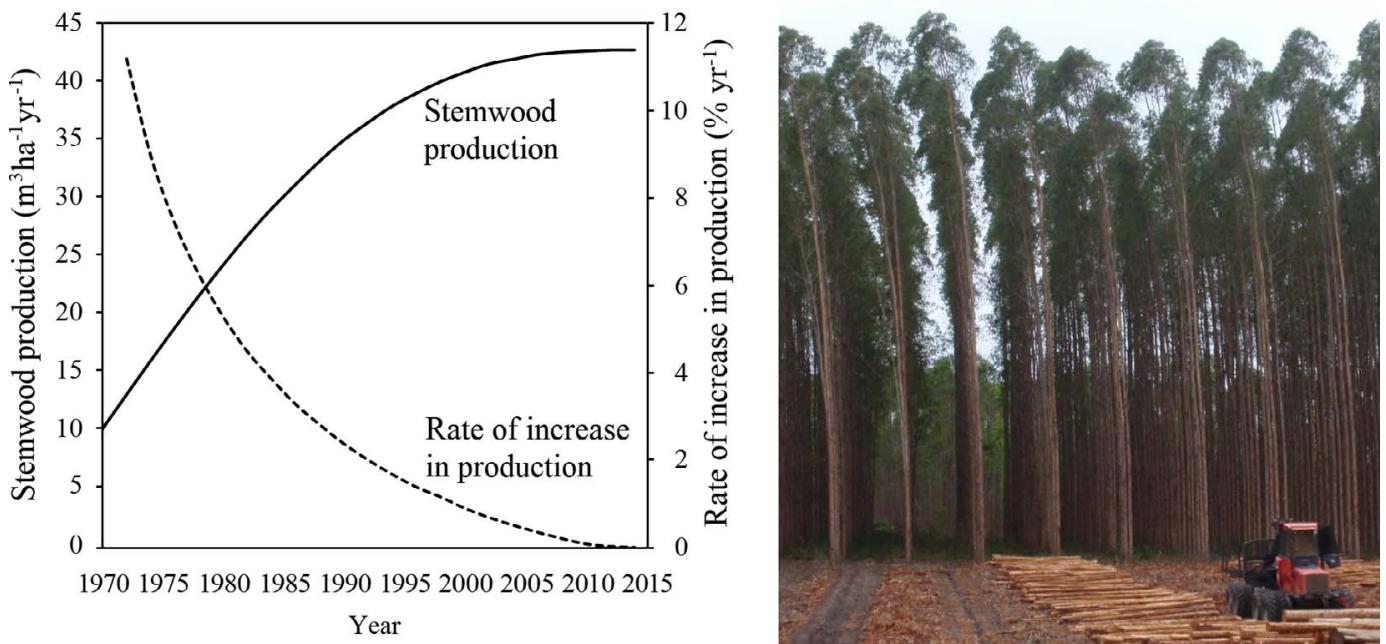

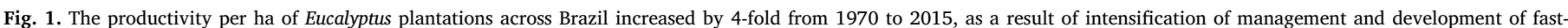

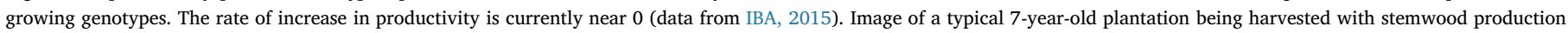
across the rotation (mean annual increment) of $25 \mathrm{Mg} \mathrm{ha}^{-1} \mathrm{yr}^{-1}$ (approximately $50 \mathrm{~m}^{3} \mathrm{ha}^{-1} \mathrm{yr}^{-1}$ ). 
Table 1

Climate description for 27 of the TECHS sites (column descriptions at bottom of table), for the growth period (24-36 months) presented in this paper.

\begin{tabular}{|c|c|c|c|c|c|c|c|c|c|c|c|c|c|c|c|c|c|}
\hline TECHS & $\begin{array}{l}\text { Lat } \\
\text { Degrees }\end{array}$ & Long & $\begin{array}{l}\text { Alt } \\
\mathrm{m}\end{array}$ & $\begin{array}{l}\text { Tavg } \\
{ }^{\circ} \mathrm{C}\end{array}$ & $\operatorname{Tmx}$ & Tmn & AGDD & $\begin{array}{l}\mathrm{T}<2{ }^{\circ} \mathrm{C} \\
\text { Number of }\end{array}$ & $\begin{array}{l}\mathrm{T}>35^{\circ} \mathrm{C} \\
\text { days } \mathrm{yr}^{-1}\end{array}$ & $\begin{array}{l}\mathrm{RH} \\
\%\end{array}$ & $\begin{array}{l}\text { RAD } \\
\text { MJ m }{ }^{-2} \mathrm{~d}^{-1}\end{array}$ & $\begin{array}{l}\text { VPDday } \\
\mathrm{kPa}\end{array}$ & VPDlight & $\begin{array}{l}\mathrm{P} \\
\mathrm{mm} \mathrm{yr}\end{array}$ & PET & AET & DEF \\
\hline 1 & -14.34 & -48.73 & 545 & 25.5 & 31.4 & 19.6 & 7472 & 0 & 39 & 61 & 21.9 & 1.6 & 2.2 & 1321 & 1644 & 1091 & 552 \\
\hline 2 & -24.21 & -49.97 & 770 & 19.0 & 23.2 & 14.7 & 5081 & 0 & 0 & 73 & 17.0 & 0.8 & 1.1 & 1495 & 1183 & 1137 & 46 \\
\hline 3 & -19.70 & -45.41 & 727 & 22.8 & 28.7 & 16.9 & 6480 & 0 & 14 & 64 & 18.7 & 1.3 & 1.9 & 946 & 1298 & 939 & 359 \\
\hline 4 & -19.31 & -42.42 & 243 & 23.6 & 28.5 & 18.7 & 6771 & 0 & 5 & 68 & 17.6 & 1.2 & 1.7 & 964 & 1215 & 957 & 258 \\
\hline 5 & -18.58 & -42.93 & 873 & 21.8 & 27.4 & 16.1 & 6099 & 0 & 0 & 68 & 18.7 & 1.1 & 1.6 & 932 & 1307 & 915 & 392 \\
\hline 6 & -30.19 & -51.62 & 150 & 21.6 & 26.2 & 16.9 & 6022 & 0 & 9 & 74 & 15.7 & 0.9 & 1.3 & 1805 & 988 & 976 & 13 \\
\hline 7 & -18.02 & -50.90 & 681 & 24.0 & 30.2 & 17.8 & 6944 & 0 & 21 & 62 & 19.0 & 1.5 & 2.1 & 1628 & 1470 & 963 & 507 \\
\hline 8 & -11.86 & -38.37 & 218 & 25.3 & 30.0 & 20.6 & 7405 & 0 & 3 & 70 & 17.5 & 1.3 & 1.8 & 896 & 1479 & 878 & 601 \\
\hline 9 & -18.73 & -47.92 & 969 & 21.8 & 26.8 & 16.7 & 6110 & 0 & 1 & 66 & 18.8 & 1.1 & 1.6 & 1412 & 1319 & 1021 & 298 \\
\hline 10 & -23.03 & -48.53 & 869 & 19.8 & 24.3 & 15.2 & 5382 & 0 & 0 & 74 & 17.9 & 0.8 & 1.2 & 1376 & 1162 & 1004 & 158 \\
\hline 11 & -18.71 & -52.59 & 783 & 23.7 & 29.1 & 18.2 & 6805 & 0 & 9 & 66 & 19.0 & 1.3 & 1.8 & 1290 & 1273 & 862 & 411 \\
\hline 12 & -19.76 & -40.13 & 36 & 25.2 & 29.8 & 20.6 & 7362 & 0 & 3 & 72 & 18.6 & 1.1 & 1.6 & 832 & 1520 & 832 & 688 \\
\hline 13 & -20.90 & -51.90 & 361 & 26.5 & 32.7 & 20.3 & 7828 & 0 & 72 & 63 & 21.4 & 1.7 & 2.4 & 1155 & 1406 & 1133 & 274 \\
\hline 14 & -19.96 & -51.59 & 480 & 24.6 & 30.8 & 18.3 & 7121 & 0 & 33 & 69 & 18.0 & 1.3 & 1.8 & 1392 & 1383 & 1093 & 291 \\
\hline 15 & -11.21 & -48.64 & 255 & 27.0 & 33.3 & 20.6 & 8000 & 0 & 80 & 66 & 20.1 & 1.7 & 2.3 & 1204 & 1520 & 1012 & 507 \\
\hline 17 & -18.25 & -45.10 & 806 & 22.9 & 28.7 & 17.0 & 6491 & 0 & 7 & 62 & 20.2 & 1.4 & 1.9 & 792 & 1610 & 746 & 864 \\
\hline 20 & -22.35 & -46.97 & 633 & 23.1 & 29.7 & 16.4 & 6576 & 0 & 22 & 62 & 17.8 & 1.5 & 2.1 & 1224 & 1274 & 1022 & 252 \\
\hline 22 & -24.23 & -50.53 & 888 & 19.8 & 23.9 & 15.6 & 5379 & 0 & 0 & 77 & 15.5 & 0.7 & 1.0 & 1554 & 1079 & 1050 & 29 \\
\hline 23 & -27.53 & -50.10 & 870 & 17.4 & 22.7 & 12.0 & 4517 & 13 & 0 & 82 & 16.3 & 0.5 & 0.8 & 2055 & 950 & 949 & 1 \\
\hline 24 & -22.73 & -49.00 & 656 & 21.4 & 28.4 & 14.4 & 5972 & 0 & 11 & 69 & 16.7 & 1.1 & 1.6 & 1701 & 1147 & 1018 & 129 \\
\hline 26 & -16.78 & -44.31 & 926 & 23.3 & 29.4 & 17.2 & 6675 & 0 & 6 & 64 & 20.8 & 1.4 & 1.9 & 477 & 1457 & 477 & 980 \\
\hline 27 & -25.98 & -50.11 & 916 & 19.0 & 24.8 & 13.1 & 5101 & 10 & 1 & 76 & 14.4 & 0.8 & 1.2 & 1487 & 819 & 817 & 1 \\
\hline 28 & -26.11 & -50.21 & 812 & 18.5 & 23.6 & 13.3 & 4896 & 8 & 0 & 78 & 14.7 & 0.7 & 1.0 & 1487 & 935 & 933 & 2 \\
\hline 29 & -3.44 & -43.07 & 81 & 28.0 & 32.7 & 23.2 & 8375 & 0 & 61 & 72 & 18.4 & 1.4 & 1.9 & 1560 & 1781 & 865 & 916 \\
\hline 30 & -17.32 & -43.77 & 848 & 22.4 & 28.7 & 16.0 & 6336 & 0 & 5 & 62 & 20.6 & 1.4 & 2.0 & 507 & 1491 & 507 & 984 \\
\hline 31 & -16.34 & -39.60 & 200 & 23.9 & 28.2 & 19.5 & 6880 & 0 & 0 & 76 & 18.3 & 0.9 & 1.3 & 982 & 1314 & 808 & 506 \\
\hline 33 & -23.85 & -48.70 & 695 & 21.0 & 26.0 & 16.0 & 5822 & 0 & 4 & 72 & 16.9 & 0.9 & 1.4 & 1357 & 1185 & 1130 & 55 \\
\hline
\end{tabular}

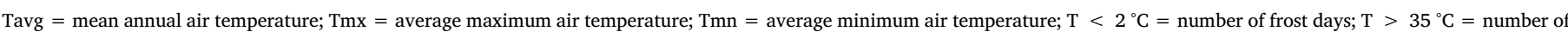

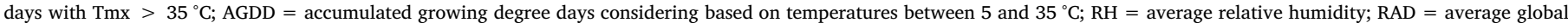

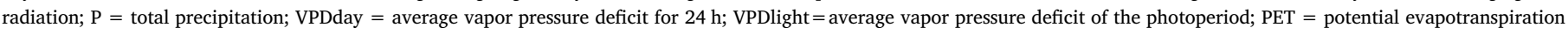

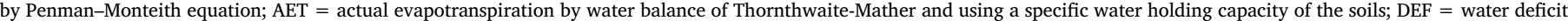
by water balance of Thornthwaite-Mather and using a specific water holding capacity of the soils.

used in this evaluation. Each clone was planted in a single plot, with 8 lines $\times 30$ trees $(24 \times 90 \mathrm{~m}$ plot $)$, with trees at a spacing of $3 \times 3 \mathrm{~m}$ (1111 trees ha $\left.{ }^{-1}\right)$. One edge of each plot had 5 rows (each with 8 trees) available for destructive sampling throughout the duration of the Project. Each plot was split, with half receiving full ambient rainfall. Rainremoval troughs were installed in the other half-plot (about a year after planting) to remove about $33 \%$ of rainfall. The rain-removal treatments were applied shortly before the mid-rotation point, so no results are available to include in the current paper.

The plot-level design was complemented with an individual-tree design, with varying spacing per tree leading to a range of ambient water supply per tree. The single-tree experiment had one plot for each clone, with uniform spacing of 3-m within 7 columns, and variable spacing between 27 trees within rows (from $0.25 \mathrm{~m}$ to $7.15 \mathrm{~m}$, or $\sim 13,000$ trees $\mathrm{ha}^{-1}$ to $\sim 450$ trees $\mathrm{ha}^{-1}$ ). All plots were fertilized intensively during the first year $\left(70 \mathrm{~kg} \mathrm{~N} \mathrm{ha}^{-1}, 45 \mathrm{~kg} \mathrm{P}^{-1}, 85 \mathrm{~kg}\right.$ $\mathrm{K} \mathrm{ha}^{-1}, 500 \mathrm{~kg} \mathrm{Ca} \mathrm{ha}^{-1}, 90 \mathrm{~kg} \mathrm{Mg} \mathrm{ha}{ }^{-1}, 40 \mathrm{~kg} \mathrm{~S}^{-1}, 3 \mathrm{~kg} \mathrm{~B} \mathrm{ha}^{-1}, 1$ $\mathrm{kg} \mathrm{Cu} \mathrm{ha}{ }^{-1}$, and $1 \mathrm{~kg} \mathrm{Zn} \mathrm{ha}^{-1}$ ) to alleviate any nutrient limitation. The schedule of fertilizer application varied among site, with the total application divided among 2-4 applications from the preplanting through 12 months. Herbicides were used to keep the plots weed-free.

The large gradient in environmental conditions (Tables 1 and 2) led to a division of sites into warmer Tropical sites and cooler Subtropical sites. Following discussions among companies' breeders, 11 commercial Brazilian Eucalyptus clones were selected among thousands available. Four clones were chosen based on expected suitability for a wide range of environmental conditions (termed "plastic" clones, Table 3), and were planted across all TECHS sites. Seven clones were chosen for suitability for warmer conditions, and were planted at all Tropical sites. Seven other clones were chosen for cooler conditions and were planted at all Subtropical sites. Each site therefore tested the four plastic clones and seven regional clones, along with a site-specific clone chosen at the discretion of the local landowner (not included in these mid-rotation results).

Genotype grouping was performed using multilocus genotypes for 20 microsatellites to estimate pairwise individual-level genetic distances among the 18 clones (pure species of $E$. grandis, E. urophylla, E. saligna, E. dunnii, E. benthamii, and hybrids) and 4 seedlots pure species (E. grandis, E. saligna, E. urophylla and E. camaldulensis) as references. The matrix of genetic distances was used to graphically represent distance relationships between the clones and pure species with an unweighted pair group method with arithmetic mean (UPGMA, Faria et al., 2011). The heterozygosity of the 18 clones was assessed using approximately 60,000 single-nucleotide polymorphisms (SNPs) following the methodology described in Silva-Junior et al. (2015). The results basically confirmed the breeders' expectations regarding two main genetic pools for clones in this study: (i) taxonomic section Maidenaria (clones F6, J1, I9, M4 and N5 of $E$. dunnii or E. benthamii); and (ii) Transversaria and Exsertaria sections (all the others; Fig. 5).

The sites showed a range of about $10{ }^{\circ} \mathrm{C}$ for both the maximum $\left(23-33^{\circ} \mathrm{C}\right)$ and minimum $\left(12-23^{\circ} \mathrm{C}\right)$ average annual temperatures (Table 1). During the 12 months of mid-rotation evaluation, the cooler sites experienced more than 8 frost days, while in the hottest sites the maximum daily temperature higher than $35{ }^{\circ} \mathrm{C}$ was observed in 40 or more days. Annual average precipitation ranged from about $400 \mathrm{~mm}$ to 
Table 2

Locations for the 27 TECHS sites in this paper, and soil characteristics (0-40 cm depth, details for column heading are below table).

\begin{tabular}{|c|c|c|c|c|c|c|c|c|c|c|c|c|c|c|c|}
\hline Site & Nearest city & Region & State & Soil order & $\begin{array}{l}\text { Clay } \\
\%\end{array}$ & Silt & Sand & $\begin{array}{l}\text { Organic } \\
\text { matter } \\
\mathrm{g} \mathrm{L}^{-1}\end{array}$ & $\mathrm{pH}$ & $\begin{array}{l}\mathrm{P} \\
\mathrm{mg} \mathrm{L}^{-1} \\
\text { soil }\end{array}$ & $\begin{array}{l}\mathrm{K} \\
\mathrm{mmol}_{\mathrm{c}} \mathrm{L}^{-3}\end{array}$ & $\mathrm{Ca}$ & $\mathrm{Mg}$ & $\begin{array}{l}\text { Cation exchange } \\
\text { capacity }\end{array}$ & $\begin{array}{l}\text { Water holding } \\
\text { capacity } \\
\mathrm{L} \mathrm{m}^{-2}\end{array}$ \\
\hline 1 & Niquelândia & $\mathrm{T}$ & GO & Oxisol & 39 & 18 & 43 & 40.0 & 4.2 & 0.0 & 0.7 & 1.0 & 1.0 & 62.7 & 166 \\
\hline 2 & Arapoti & $\mathrm{T}$ & PR & Oxisol & 71 & 22 & 7 & 34.3 & 4.1 & 0.0 & 0.6 & 1.0 & 1.0 & 91.4 & 240 \\
\hline 3 & Bom Despacho & $\mathrm{T}$ & MG & Oxisol & 79 & 19 & 2 & 45.0 & 4.4 & 0.0 & 0.5 & 1.0 & 1.0 & 76.5 & 246 \\
\hline 4 & Belo Oriente & $\mathrm{T}$ & MG & Oxisol & 59 & 10 & 31 & 31.3 & 4.0 & 1.5 & 1.2 & 4.8 & 1.3 & 71.7 & 179 \\
\hline 5 & Guanhães & $\mathrm{T}$ & MG & Oxisol & 44 & 13 & 43 & 35.0 & 3.9 & 0.5 & 0.9 & 1.3 & 1.0 & 91.1 & 160 \\
\hline 6 & Eldorado do Sul & ST & RS & Ultisol & 27 & 19 & 54 & 25.0 & 3.7 & 0.5 & 1.0 & 1.0 & 1.0 & 128.0 & 145 \\
\hline 7 & Rio Verde & $\mathrm{T}$ & GO & Entisol & 6 & 5 & 89 & 19.0 & 4.5 & 2.5 & 0.3 & 9.5 & 1.0 & 35.8 & 59 \\
\hline 8 & Inhambupe & $\mathrm{T}$ & BA & Ultisol & 18 & 7 & 75 & 18.0 & 4.1 & 4.5 & 0.8 & 1.0 & 1.0 & 37.3 & 89 \\
\hline 9 & Estrela do Sul & $\mathrm{T}$ & MG & Oxisol & 80 & 9 & 11 & 43.0 & 3.9 & 1.0 & 0.8 & 2.0 & 1.0 & 88.8 & 215 \\
\hline 10 & Botucatu & ST & SP & Oxisol & 20 & 9 & 71 & 30.0 & 4.3 & 3.5 & 2.2 & 4.0 & 1.0 & 66.7 & 100 \\
\hline 11 & Chapadão do Sul & $\mathrm{T}$ & MS & Oxisol & 15 & 9 & 76 & 23.5 & 4.3 & 1.5 & 0.5 & 3.0 & 1.0 & 55.0 & 91 \\
\hline 12 & Aracruz & $\mathrm{T}$ & ES & Oxisol & 30 & 12 & 58 & 18.0 & 4.0 & 1.5 & 0.7 & 2.5 & 1.0 & 40.7 & 130 \\
\hline 13 & Três Lagoas & $\mathrm{T}$ & MS & Oxisol & 14 & 9 & 77 & 11.0 & 4.0 & 3.0 & 5.2 & 24.5 & 4.5 & 62.7 & 87 \\
\hline 14 & Inocência & $\mathrm{T}$ & MS & Entisol & 10 & 8 & 82 & 10.5 & 4.1 & 1.0 & 6.8 & 28.5 & 5.0 & 64.8 & 79 \\
\hline 15 & $\begin{array}{l}\text { Brejinho de } \\
\text { Nazaré }\end{array}$ & $\mathrm{T}$ & TO & Entisol & 10 & 8 & 82 & 7.5 & 4.2 & 0.0 & 4.1 & 35.5 & 5.0 & 64.6 & 77 \\
\hline 17 & Três Marias & $\mathrm{T}$ & MG & Oxisol & 14 & 5 & 81 & 15.5 & 4.1 & 0.5 & 2.9 & 11.5 & 2.0 & 47.4 & 76 \\
\hline 20 & Mogi Guaçu & $\mathrm{T}$ & SP & Oxisol & 41 & 16 & 42 & 34.0 & 4.1 & 4.5 & 1.2 & 8.0 & 1.5 & 97.2 & 165 \\
\hline 22 & Telemaco Borba & $\mathrm{T}$ & PR & Oxisol & 56 & 23 & 21 & 52.0 & 4.0 & 3.5 & 3.8 & 37.5 & 11.0 & 183.8 & 214 \\
\hline 23 & Otacílio Costa & ST & SC & Inceptisol & 43 & 28 & 29 & 44.5 & 3.9 & 0.5 & 7.5 & 67.0 & 10.5 & 338.0 & 205 \\
\hline 24 & Borebi & $\mathrm{T}$ & SP & Entisol & 8 & 3 & 89 & 12.0 & 4.6 & 2.0 & 5.5 & 73.0 & 10.0 & 104.5 & 57 \\
\hline 26 & Coração de Jesus & $\mathrm{T}$ & MG & Oxisol & 35 & 6 & 59 & 32.0 & 3.9 & 1.5 & 5.1 & 48.5 & 7.5 & 120.6 & 118 \\
\hline 27 & Antônio Olinto & ST & PR & Ultisol & 14 & 5 & 81 & 25.5 & 3.9 & 3.5 & 4.5 & 31.5 & 6.0 & 141.5 & 76 \\
\hline 28 & Três Barras & ST & SC & Oxisol & 60 & 24 & 16 & 51.0 & 3.8 & 1.5 & 1.6 & 30.5 & 5.5 & 291.1 & 225 \\
\hline 29 & Urbano Santos & $\mathrm{T}$ & MA & Entisol & 9 & 5 & 87 & 16.0 & 4.1 & 0.0 & 1.4 & 36.5 & 15.5 & 91.4 & 64 \\
\hline 30 & Bocaiúva & $\mathrm{T}$ & MG & Oxisol & 76 & 14 & 10 & 47.5 & 3.9 & 2.0 & 1.6 & 48.5 & 26.5 & 209.1 & 225 \\
\hline 31 & Eunápolis & $\mathrm{T}$ & BA & Ultisol & 25 & 3 & 73 & 24.5 & 5.4 & 5.0 & 1.5 & 25.5 & 9.0 & 60.0 & 88 \\
\hline 33 & Buri & ST & SP & Oxisol & 52 & 20 & 28 & 51.0 & 4.3 & 10.5 & 1.0 & 11.0 & 14.5 & 135.5 & 196 \\
\hline
\end{tabular}

Region: Tropical (T), Subtropical (ST).

Soil order: by US taxonomy, Soil Survey Staff (1999).

Clay and sand were quantified by densiometer method (Embrapa, 1997).

Organic matter was determined by Walkley-Black method (Embrapa, 1997).

Extractable P, K, Ca, e Mg were extracted by ion exchange resin (van Raij et al., 2001).

CEC (cationic exchange capacity).

WHC (water holding capacity, 0-2 m depth, Stape et al., 2004).

Table 3

The 18 TECHS genotypes of Eucalyptus, genetic heterozygosity, and the climate where each clone was developed for operational use.

\begin{tabular}{|c|c|c|c|c|}
\hline Clone & Genotype & Clone type & Heterozygosity & $\begin{array}{l}\text { Climate of the } \\
\text { clone origin } \\
\text { region }^{\text {a }}\end{array}$ \\
\hline A1 & E. urophylla & Plastic & 0.245 & Cwa \\
\hline B2 & $\begin{array}{l}\text { E. urophylla } \times E . \\
\text { grandis }\end{array}$ & Tropical & 0.247 & Aw \\
\hline C3 & $\begin{array}{l}\text { E. grandis } x E \text {. } \\
\text { camaldulensis }\end{array}$ & Plastic & 0.294 & As \\
\hline D4 & $\begin{array}{l}\text { E. grandis } x E \text {. } \\
\text { urophylla }\end{array}$ & Tropical & 0.243 & Aw \\
\hline E5 & E. urophylla & Tropical & 0.243 & Cwa \\
\hline F6 & E. benthamii & Subtropical & 0.091 & $\mathrm{Cfb}$ \\
\hline G7 & E. urophylla & Tropical & 0.251 & Cwa \\
\hline H8 & $\begin{array}{l}\text { E. grandis } x E \text {. } \\
\text { urophylla }\end{array}$ & Tropical & 0.258 & $\mathrm{Am}$ \\
\hline I9 & E. dunnii & Subtropical & 0.105 & $\mathrm{Cfb}$ \\
\hline $\mathrm{J} 1$ & E. benthamii & Subtropical & 0.092 & $\mathrm{Cfb}$ \\
\hline K2 & E. saligna & Plastic & 0.211 & $\mathrm{Cfb}$ \\
\hline L3 & $\begin{array}{l}\text { E. urophylla } \times E \text {. } \\
\text { globulus }\end{array}$ & Subtropical & 0.230 & $\mathrm{Cfb}$ \\
\hline M4 & E. dunnii & Subtropical & 0.102 & $\mathrm{Cfb}$ \\
\hline N5 & E. dunnii & Subtropical & 0.106 & $\mathrm{Cfb}$ \\
\hline O6 & E. grandis & Subtropical & 0.181 & $\mathrm{Cfb}$ \\
\hline P7 & $\begin{array}{l}\text { E. urophylla } x E \text {. } \\
\text { tereticornis }\end{array}$ & Tropical & 0.234 & As \\
\hline Q8 & E. grandis & Plastic & 0.240 & Af \\
\hline R9 & E. urophylla & Tropical & 0.251 & Aw \\
\hline
\end{tabular}

${ }^{\text {a }}$ Köppen climatic classification (Alvares et al., 2013b).
$2000 \mathrm{~mm}$ (Fig. 4), and potential evapotranspiration (Thornthwaite and Mather, 1957) ranged from about 800 to $1800 \mathrm{~mm} \mathrm{yr}^{-1}$. Accounting for the water holding capacity of soil at each site, the annual water deficit (water balance of Thornthwaite and Mather, 1957) ranged from 0 for cooler and wetter sites to over $800 \mathrm{~mm} \mathrm{yr}^{-1}$ on the hotter, drier sites.

Soils varied substantially among the TECHS sites, including one site on a clayey Inceptisol, five sites on sandy Entisols, four sites on highly weathered, high-clay Ultisols, and seventeen on highly weathered Oxisols (Table 2). Soil water holding capacity (0-2 $\mathrm{m}$ depth) differed by up to fourfold across sites, increasing from about $75 \mathrm{~mm} \mathrm{~m}^{-1}$ for soils with $10 \%$ clay to over $200 \mathrm{~mm} \mathrm{~m}^{-1}$ for soils with $80 \%$ clay. All soils were very acidic, with low to moderate levels of extractable phosphorus, nutrient cations, and cation exchange capacity. Cation exchange capacity related more strongly to soil organic matter $\left(\mathrm{r}^{2}=0.45\right.$, $\mathrm{P}<0.001)$ than to clay content $\left(\mathrm{r}^{2}=0.2, \mathrm{P}=0.05\right)$.

The diameter at breast height (DBH, $1.3 \mathrm{~m}$ above ground level), total height $(\mathrm{H})$, and live crown depth of all trees and sites were measured every 6 months. Stemwood biomass was estimated by allometric equations developed from destructive sampling of 93 trees from the 18 clones (3-6 trees per clone) at site 33 (which uniquely was planted with all 18 genotypes). The sampled trees were selected to cover the range of DBH. After harvesting, DBH and total height $(\mathrm{H})$ were measured. Stemwood was separated from the other components of the tree and weighed on site individually, and representative samples were collected and dried at $65{ }^{\circ} \mathrm{C}$ to constant weight for dry mass determination.

Dry mass (B, in $\mathrm{kg}$ tree $^{-1}$ ) of the stemwood compartment was calculated using the linearized model of Schumacher and Hall (1933), 

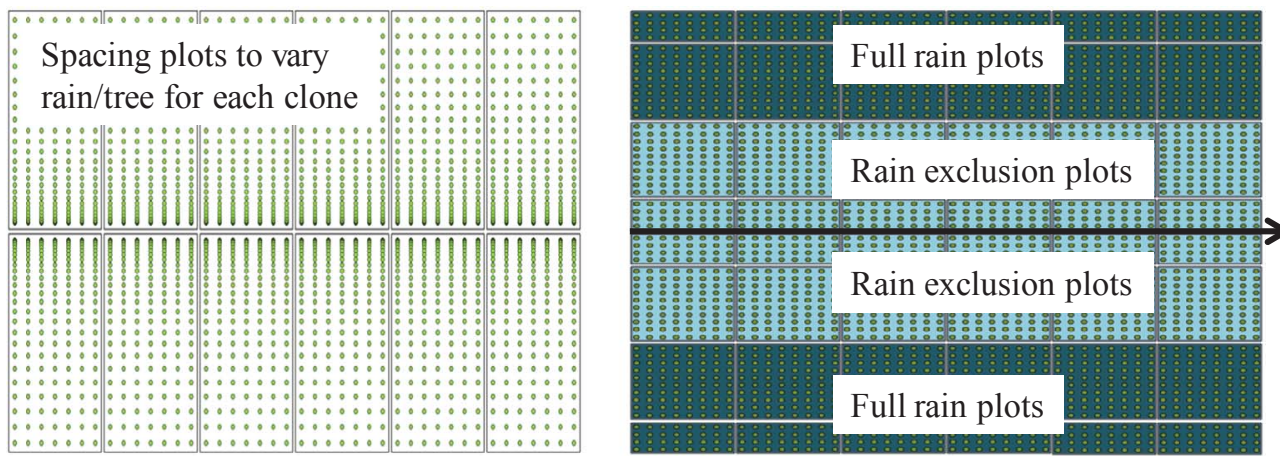

1
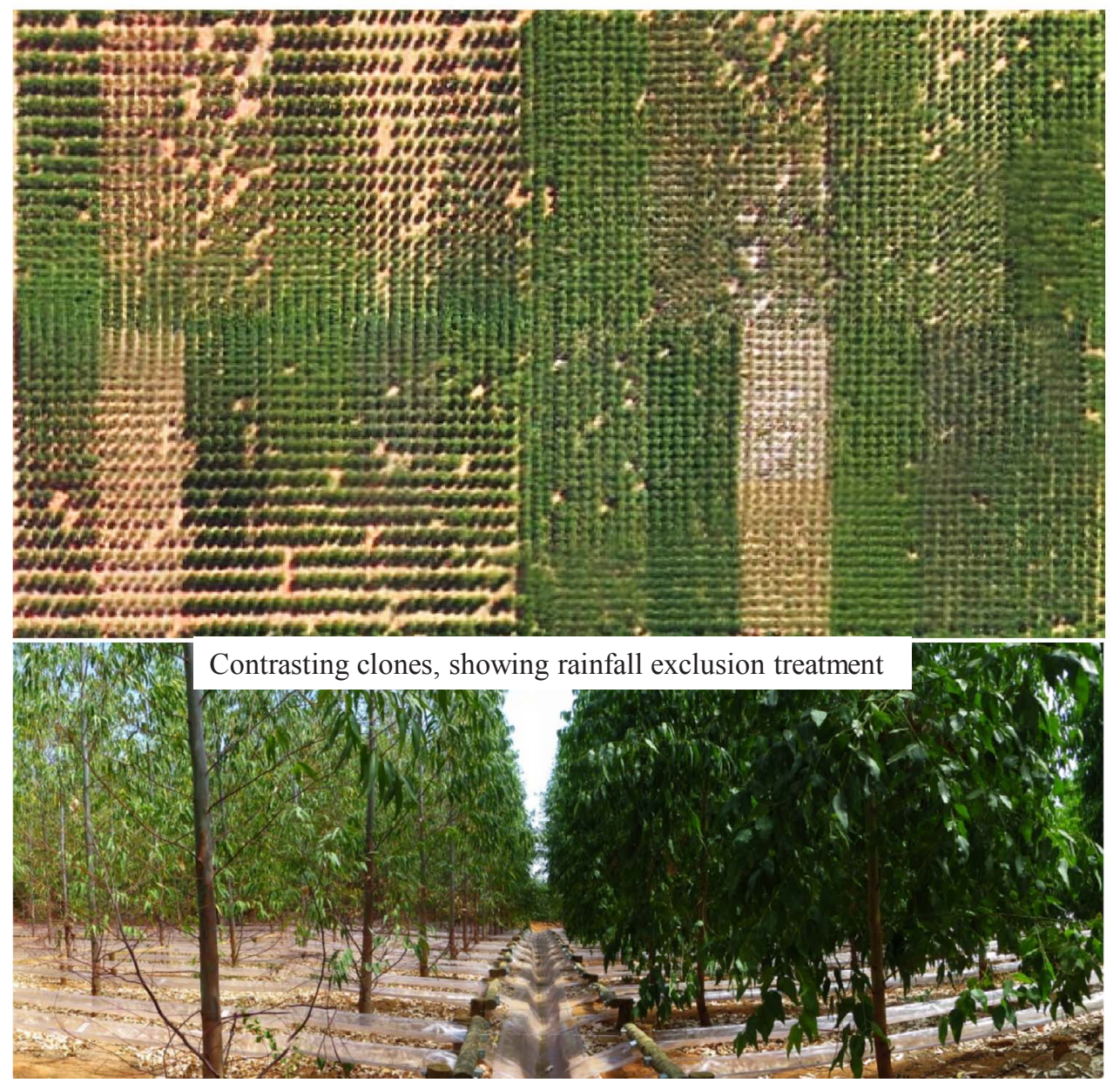

Fig. 2. Diagram (upper) and photograph (middle) of TECHS design. For the individual-tree experiment with spacing (left side of upper and middle images), each of the 12 clones used at each site was planted in 7 lines of trees ( $3 \mathrm{~m}$ spacing) and 27 variable spacing between trees within rows (ranging from 0.25 to $7.15 \mathrm{~m}$ apart), providing a range from $1.5 \mathrm{~m}^{2}$ tree ${ }^{-1}$ $\left(\sim 13,000\right.$ trees ha $\left.{ }^{-1}\right)$ to $23 \mathrm{~m}^{2}$ tree $^{-1}(\sim 450$ trees $\left.\mathrm{ha}^{-1}\right)$. The rainfall removal experiment (right side of upper and middle figures) planted trees in single-clone plots $(24 \times 30 \mathrm{~m}$, with trees at $3 \times 3 \mathrm{~m}$ spacing), with additional rows of trees to allow for destructive sampling. The rainfall removal troughs are shown for 2 clones in the bottom image. with specific intercept "a" for each clone $j\left(\mathrm{R}_{\mathrm{adj}}^{2}=0.98, \mathrm{MAE}=0.04 \mathrm{~kg}\right.$ tree $^{-1}$ ) (Mattos, 2015):

$\ln B j=a j+1,8534 \ln (D B H)+1,1414 \ln (H)$

The best allometric equation was selected by the graphical analysis of normality and distribution of the residuals, the range of prediction of mean absolute error (MAE, Willmott and Matsuura, 2005), and the adjusted determination coefficient. The coefficients were fitted using the ordinary least squares of the function $\mathrm{lm}$ in R (R Core Team, 2014). The "a" intercept varied from -4.4530 to -4.0682 . Stemwood production between years 2 and 3 was estimated for each clone and site as the summation of the individual tree stem biomass increases (based on clone-specific allometrics), dividing by the plot area and expanding to a hectare basis $\left(\mathrm{Mg} \mathrm{ha}^{-1} \mathrm{yr}^{-1}\right)$.

Leaf area index (LAI) was estimated based on the theory of Norman and Jarvis (1975), using a ceptometer (AccuPAR LP-80, Decagon Devices Inc., 1999). The method accounts for sky conditions at the time of radiation measurement, effects of the canopy structure, and foliage optical properties, assuming random foliage orientation distribution radiation extinction coefficient of 0.5 (Campbell, 1986, Wang et al., 2007; see Mattos, 2015 for more details).

The patterns of stemwood production across gradients in precipitation and temperature were evaluated with CurveExpert version 2.4 (http://www.curveexpert.net/). The best-fit equation was chosen 


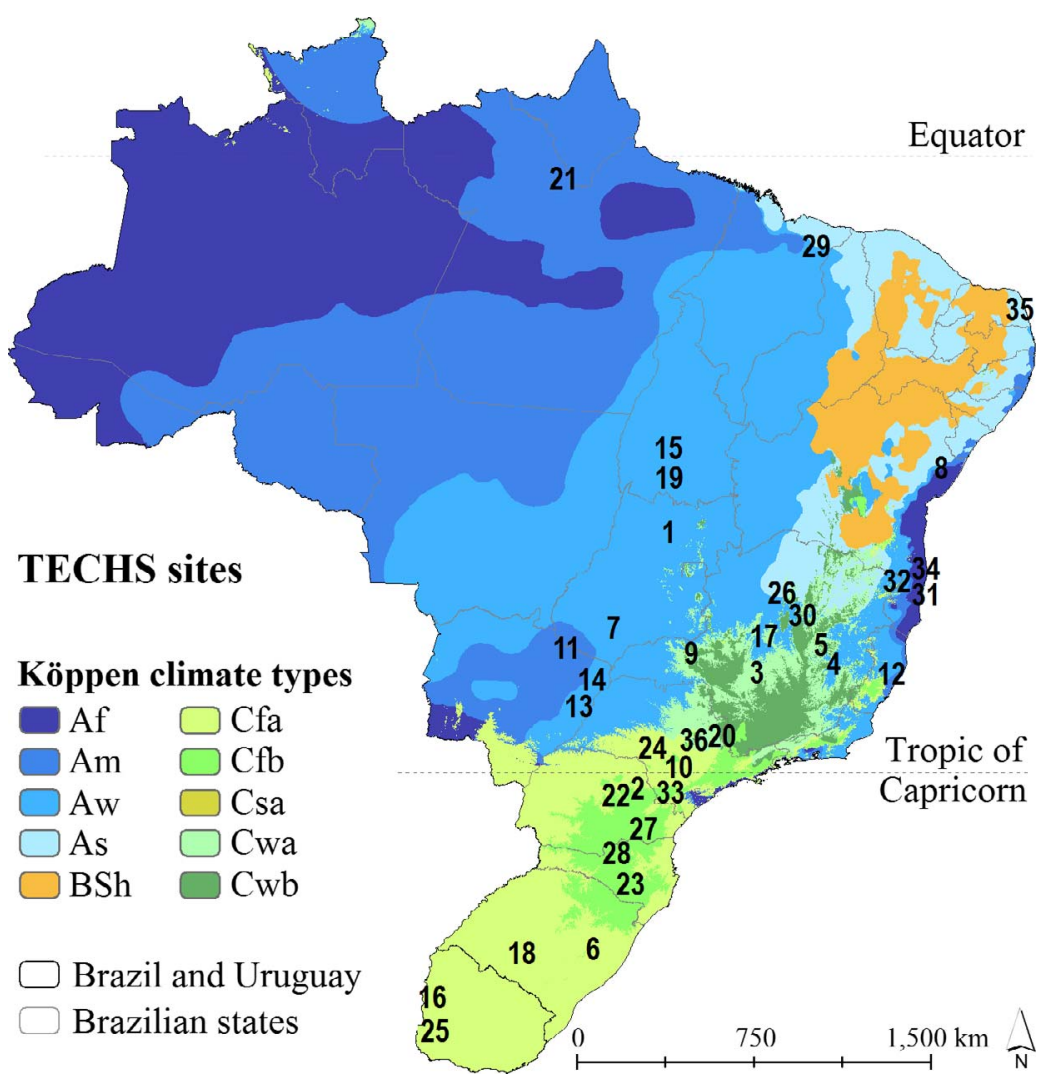

Fig. 3. Location and climate classification of all 36 of the TECHS sites across a $3500 \mathrm{~km}$ geographic gradient (climate types from Alvares et al., 2013a,b). based on the lowest AICc (Akaike's Information Criterion corrected for small smaple size) adjusted for small sample sizes.

\section{Results}

The weather patterns across the TECHS sites were generally typical of long-term climate patterns, with no extreme droughts or excessive rains. The TECHS sites and clones showed a wide range of leaf area and growth, as expected. Fig. 6 illustrates the response of two clones to the environmental conditions across 3 sites. Clone A1 was most productive at Site 22, producing $34 \mathrm{Mg} \mathrm{ha}^{-1} \mathrm{yr}^{-1}$ of stemwood, with the light intercepted by a leaf area index of 3.8. Clone A1 produced about the same LAI on sites 20 and 30, but growth was only 19 and $22 \mathrm{Mg} \mathrm{ha}^{-1}$ $\mathrm{yr}^{-1}$. The large difference in stem production across the sites related not to leaf area and light interception, but to the efficiency of producing wood per unit of light intercepted. Similar to Clone A1, Clone C3 was the most productive at site $22\left(46 \mathrm{Mg} \mathrm{ha}^{-1} \mathrm{yr}^{-1}\right.$ with a LAI of 3.0), but produced about the same stemwood as Clone A1 on Sites 20 and 30, despite $33 \%$ lower LAI. The lack of a difference in stem production in this case resulted from a higher LAI and efficiency of light use at Site 20 for Clone 3. Differences in leaf assimilation and respiration, carbon allocation and local herbivory rates can influence light use efficiency, and future research will estimate the influences of these factors.

The environmental gradient across the Tropical region led to a 5fold range in stem production (9-45 $\mathrm{Mg} \mathrm{ha}^{-1} \mathrm{yr}^{-1}$, site averages for all clones within each site, Fig. 7). The variation across sites was not as large for the Subtropical region, differing only about 2-fold (19 and $44 \mathrm{Mg} \mathrm{ha}^{-1} \mathrm{yr}^{-1}$ ). The production of the best and worst clone differed by a factor of 2 or more for both the Tropical and Subtropical regions. The grand average of all clones within the Tropical region $\left(21 \mathrm{Mg} \mathrm{ha}^{-1}\right.$ $\mathrm{yr}^{-1}$ ) was $25 \%$ lower than Subtropical region $\left(28 \mathrm{Mg} \mathrm{ha}^{-1} \mathrm{yr}^{-1}\right.$ ). Within each site, stemwood production of the clones differed between the more productive tropical sites and the subtropical sites.

The productivity of each clone varied substantially across sites (Fig. 8). Clone P7 (planted only in the Tropical region) showed relatively low variation in production, indicating a limited ability to reach high growth rates even on favorable sites. Clones $\mathrm{H} 8$ and $\mathrm{B} 2$ were the most variable across sites in the Tropical region, achieving high growth rates on the best sites, but much less on poorer sites. The clones planted only in the Subtropical sites showed generally less variation across sites than those in the Tropical region. Within the Tropical region variation was lowest for the poorest sites (Fig. 7), perhaps indicating a single overriding factor such as water supply strongly limited the expression of genotypic differences. The plastic clones that were planted in both regions showed high variation in the Tropical region, similar to the Tropical-only clones (Fig. 8). The potential growth of Eucalyptus at each site may be indexed better by the production of the best clones. The average growth of the three fastest-growing clones (at each site) averaged about $1.5-4 \mathrm{Mg} \mathrm{ha} \mathrm{yr}^{-1}\left(3-8 \mathrm{~m}^{3} \mathrm{ha}^{-1} \mathrm{yr}^{-1}\right)$ more than the average for all clones $\left(22 \mathrm{Mg} \mathrm{ha}^{-1} \mathrm{yr}^{-1}\right)$.

These patterns of production for the clones across sites are also illustrated in Fig. 9, where the clones are ranked for each region. Plastic Clone A1 was a top performer overall for the Tropical region (ranked as the best performer for the greatest number of sites), but A1 ranked near the middle for the Subtropical region. Plastic Clone C3 was near the bottom for performance on Tropical region, but did better than the other three plastic clones in the Subtropical region. The regional pattern of production for Clone C3 may relate to the distribution of a gallwasp (absent from some of the Tropical sites and from the Subtropical region). 


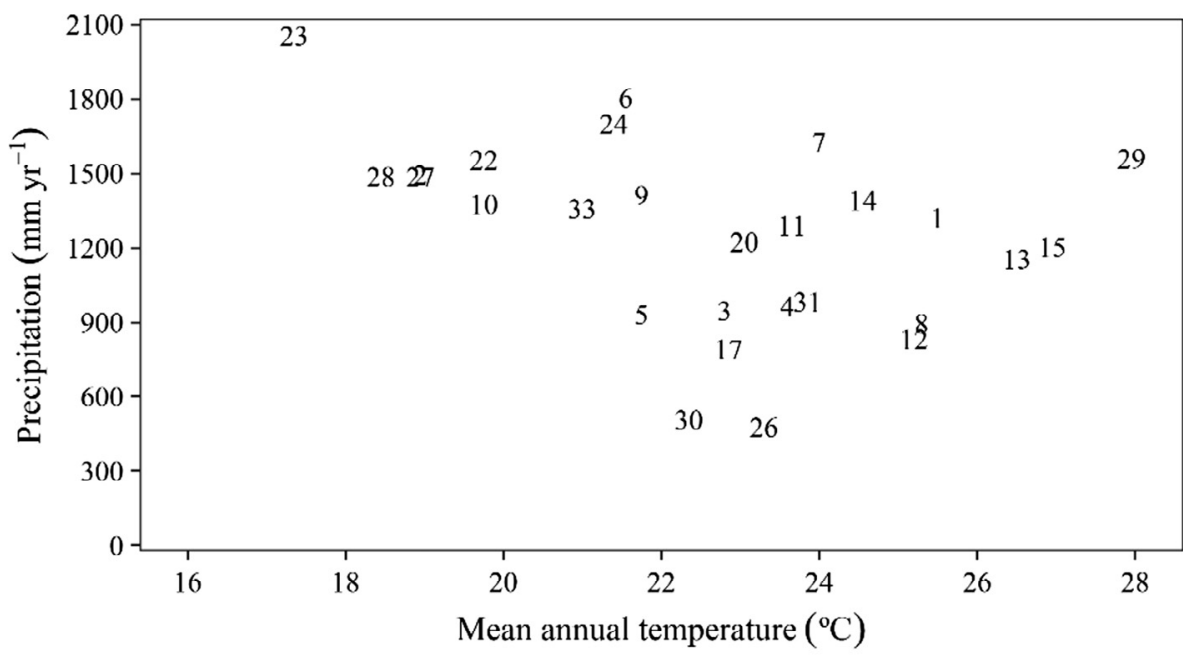

Fig. 4. The average annual precipitation for the TECHS sites spanned a fourfold range, along with a $10{ }^{\circ} \mathrm{C}$ temperature range (upper graph). The combination of water supply and temperature provided estimated water deficits (lower graph) of $0-1000 \mathrm{~mm} \mathrm{yr}^{-1}$ (based on temperature, precipitation, and water holding capacity of soil in each site).

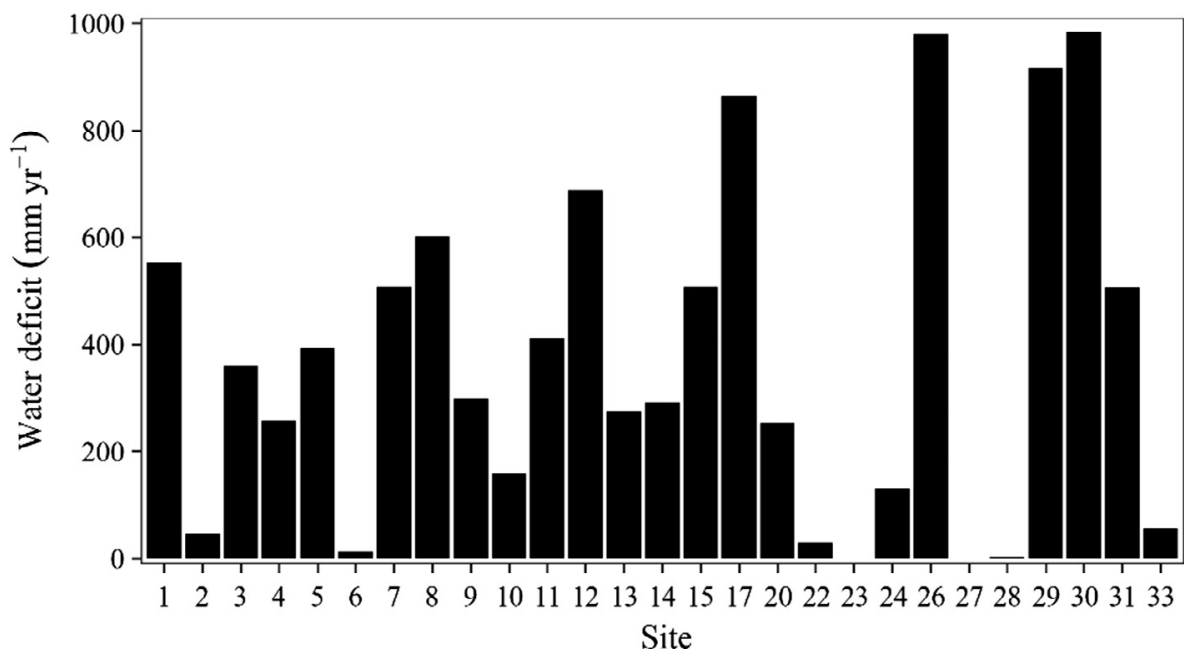

Across sites the annual rainfall from year 2 to 3 ranged from 500 to $2000 \mathrm{~mm}$, and mean annual temperature ranged from 17 to $27^{\circ} \mathrm{C}$. The average growth of clones across all sites showed linear relationships with both temperature and precipitation. An increase of precipitation of $100 \mathrm{~mm} \mathrm{yr}^{-1}$ was associated with a $1.51 \mathrm{Mg} \mathrm{ha}^{-1} \mathrm{yr}^{-1}\left(\mathrm{r}^{2}=0.21\right.$, $\mathrm{P}=0.03$ ) increase in stemwood production across all clones, and $1.79 \mathrm{Mg} \mathrm{ha}{ }^{-1} \mathrm{yr}^{-1}\left(\mathrm{r}^{2}=0.28, \mathrm{P}=0.01\right)$ when considering only the 3 best clones for each site. An increase of $1{ }^{\circ} \mathrm{C}$ in mean annual temperature was associated with a decline in stemwood production of $2.9 \mathrm{Mg} \mathrm{ha}^{-1} \mathrm{yr}^{-1}$ for all clones and for the three best clones $\left(\mathrm{r}^{2}=0.35\right.$, $\mathrm{P}<0.01$ ).

The geographic patterns in precipitation and temperature were not independent. Hotter sites were generally drier, with precipitation decreasing by an average of $78 \mathrm{~mm} \mathrm{yr}^{-1}$ for $1{ }^{\circ} \mathrm{C}$ increase in mean annual temperature $\left(\mathrm{r}^{2}=0.27, \mathrm{P}=0.01\right)$. Simple correlations with production as a function of temperature had about the same AICc (within 1 unit) as the more complex relationship with both temperature and precipitation. The pattern of growth with precipitation alone was weaker (AICc about 4 units higher) than when both precipitation and temperature were included. The apparent response of production to precipitation was substantially lower when temperature was also included as an independent variable, declining to an increase of only $0.43 \mathrm{Mg} \mathrm{ha}{ }^{-1} \mathrm{yr}^{-1}$ with an increase of $100 \mathrm{~mm}$ of precipitation (Fig. 10). The apparent influence of temperature on production was similar when examined in relation to temperature and precipitation
(2.5 $\mathrm{Mg} \mathrm{ha}{ }^{-1} \mathrm{yr}^{-1}$ for a $1{ }^{\circ} \mathrm{C}$ change in temperature) as it was with temperature alone.

The influence of temperature and precipitation may be combined into a single variable of a water deficit, incorporating the energy available to evaporate water, and the supply of water based on precipitation and soil water-holding capacity (Table 1). Condensing these influences into the single variable of water deficit lowered the AICc (by about 4 units) and raised the $\mathrm{r}^{2}$ (from 0.37 to 0.45 ) for predicting stem production relative to using temperature and precipitation as independent variables, highlighting that temperature and water together with soil physical drainage properties influences clone adaptation and performance.

Clones varied strongly in responsiveness to differences in climate across sites. The clone with the highest average growth across the Tropical sites (Clone D4) showed very high growth at cooler Tropical sites, and a linear response to precipitation (Fig. 10). In contrast, the best-growing plastic clone (across both regions, A1) showed a relatively large plateau of growth, declining at all extremes. Interestingly, the different curvilinear responses of individual clones led to the overall linear pattern in the upper part of Fig. 10(A and B) when multiple clones were averaged together.

In the spacing experiment, the trees planted at the widest spacing showed the highest individual tree growth (Fig. 11). All clones showed declining individual tree size as distance to neighbors declined, though some were notably more sensitive than others. The influence of 


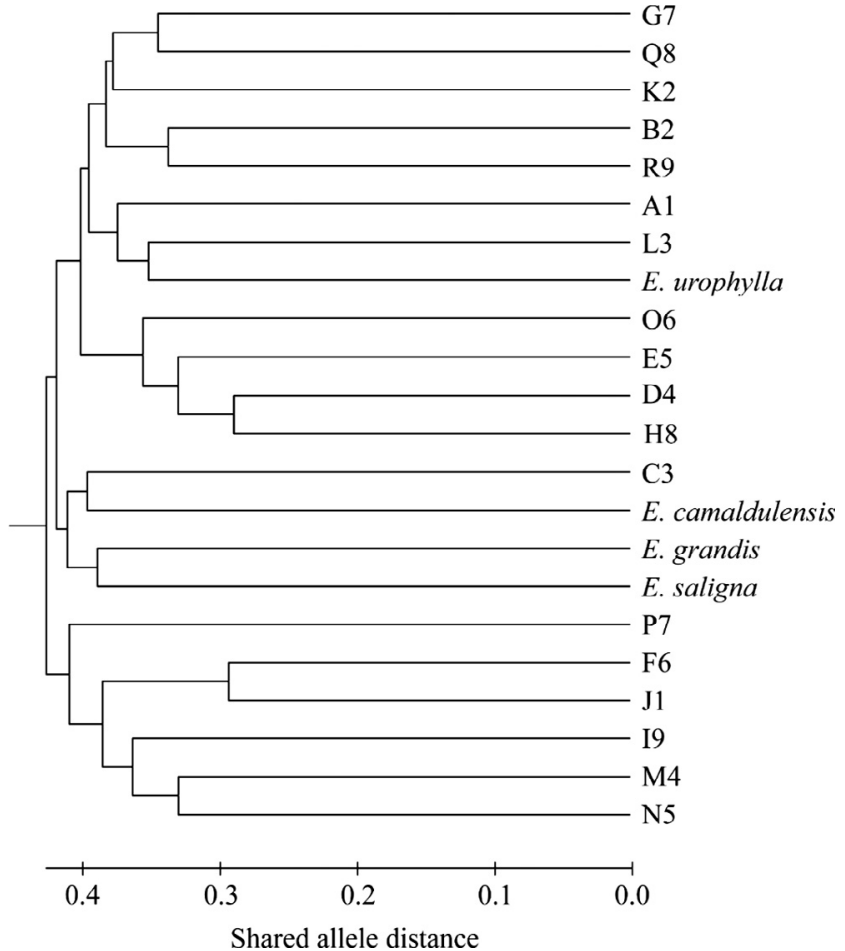

Fig. 5. TECHS clones came from two main genetic pools of the Eucalyptus genera: (i) Section Maidenaria (clones F6, J1, I9, M4 and N5 of E. dunnii or E. benthamii); and (ii) Sections Transversaria and Exsertaria (all the others clones and the 4 seedlot species).

neighbors was much stronger for the Tropical sites than for the cooler and wetter Subtropical sites, based on the average response of all clones within each site. The individual tree patterns can be extrapolated to a plot scale based on the area available to each tree. The plot-level production increased somewhat for each clone with increasing density of tree spacing, but the pattern differed strongly among the clones. When all clones are averaged within each site, the Subtropical sites showed the strongest plot-level response to density of tree spacing. This results from a weaker effect of spacing on individual tree growth (Fig. 11B), allowing the number of trees to then have a larger overall effect on plotlevel growth (Fig. 11C).

\section{Discussion}

The broad range of climate, soils, and genotypes in the TECHS project provided a strong platform for evaluating patterns of stem production. Three findings were especially intriguing. The range of precipitation across the TECHS sites was associated with a threefold range in stemwood growth, about the magnitude of response to temperature. Although both precipitation and temperature showed similar magnitudes of influence on stemwood production, the effect of temperature was statistically stronger. The temperature response was negative, in contrast to typical regional patterns that include changes of species across temperature gradients in the Tropics. For example, Beer et al. (2010) examined the pattern of gross primary production (GPP) as a function of latitude, and found GPP decreased with distance from the Equator as temperatures declined.

The negative effect of warmer temperatures could result from increasing respiration loss of carbon. Ecosystem respiration generally increases with temperature, with a typical increase of $40 \%$ for a $10{ }^{\circ} \mathrm{C}$ increase in temperature (Mahecha et al., 2010). However, the TECHS Project stemwood production showed a much steeper response to the geographic temperate gradient, with a $40 \%$ decline in stemwood production in response to only a $4{ }^{\circ} \mathrm{C}$ increase in temperature. Therefore we suspect that a temperature response of respiration would likely be too small to account for the bulk of the decline in stemwood production.

Perhaps the most relevant examination of possible factors comes from Aspinwall et al. (2016), with an examination of long-term and short-term temperature responses of Eucalyptus tereticornis grown under controlled conditions. They found strong declines in both photosynthetic capacity (at saturating levels of $\mathrm{CO}_{2}$ ) and nighttime respiration of leaves with increasing temperatures. Taking $20^{\circ} \mathrm{C}$ as a baseline, increasing temperature to $24^{\circ} \mathrm{C}$ lowered photosynthetic capacity by $17 \%$ and nighttime respiration by $29 \%$. An increase of $4{ }^{\circ} \mathrm{C}$ across the TECHS site was associated with a notably larger reduction in stemwood production, so these mechanisms may not be sufficient to explain the TECHS pattern. Overall, the TECHS Project shows that direct assessment of tree ecophysiology and carbon partitioning will be needed to explain the strong decline we observed in stem production with increasing temperature across the geographic gradient, as found by Stape et al. (2008) and Ryan et al. (2010).

A second major point is that the TECHS pattern of production in response to precipitation (about $1.5 \mathrm{Mg} \mathrm{ha}^{-1} \mathrm{yr}^{-1}$ for each increase of $100 \mathrm{~mm} \mathrm{yr}^{-1}$ in precipitation) was similar to trends reported for inventory plots across geographic gradients in eastern Brazil (Fig. 12). Stape et al. (2004) estimated an increase of $2.2 \mathrm{Mg} \mathrm{ha}^{-1} \mathrm{yr}^{-1}$ for each $100 \mathrm{~mm} \mathrm{yr}^{-1}$ increase in precipitation (Fig. 12) across 14 sites in northern Bahia. A database with thousands of operational inventory plots also showed a similar response to increasing precipitation in southern Bahia, northern Espirito Santo, and eastern Minas Gerais, where an increase of $100 \mathrm{~mm} \mathrm{yr}^{-1}$ was associated with increased production of $2.4 \mathrm{Mg} \mathrm{ha}{ }^{-1} \mathrm{yr}^{-1}$ on drier sites (about $1000 \mathrm{~mm} \mathrm{yr}^{-1}$ mean annual precipitation) and $1.5 \mathrm{Mg} \mathrm{ha}^{-1} \mathrm{yr}^{-1}$ on wetter sites (about $1500 \mathrm{~mm} \mathrm{yr}^{-1}$; (J.L. Stape, unpublished data).

As noted above, these apparent effects of increasing precipitation may be confounded with changes in temperature across geographic gradients. Any influence of temperature may be excluded by testing response to either additions or removals of water within sites. Irrigation treatments in Eucalyptus plantations in Brazil have shown about $0.66 \mathrm{Mg} \mathrm{ha}^{-1} \mathrm{yr}^{-1}$ additional stemwood production for each $100 \mathrm{~mm}$ of irrigation water (Stape et al. 2010). This irrigation was close to the TECHS value of $0.43 \mathrm{Mg} \mathrm{ha}^{-1} \mathrm{yr}^{-1}$ for each $100 \mathrm{~mm}$ increase in rainfall across sites (when the effect of temperature was included). A relatively modest response of stemwood production to water supply was also evident in a rainfall removal experiment in São Paulo. Removal of 37\% of throughfall beneath Eucalyptus trees had little effect on forest production, though tree nutrition (particularly potassium supply) and deep-soil drawdown of stored water were also important (Christina et al., 2015, Laclau, 2016).

A third major point is that the TECHS Project indicated that the overall patterns of stem production varied as strongly among clones within sites as across the geographic gradient of sites. As illustrated in Fig. 6, the clones differed greatly in the deployment of leaf area, and in the ability of leaves to grow wood. The clones also differed strongly in response to temperature and precipitation (Fig. 10). On-going studies are examining some of the processes that underlie these patterns. The wide range of responses among clones to the geographic gradient in the TECHS study demonstrates opportunities for matching genotypes, and even genes, to sites. We anticipate that on-going investigation of genetic markers among the clones in this study may relate to the degree of 
Clone A1: Site 22

Leaf area index: $3.8 \mathrm{~m}^{2} \mathrm{~m}^{-2}$
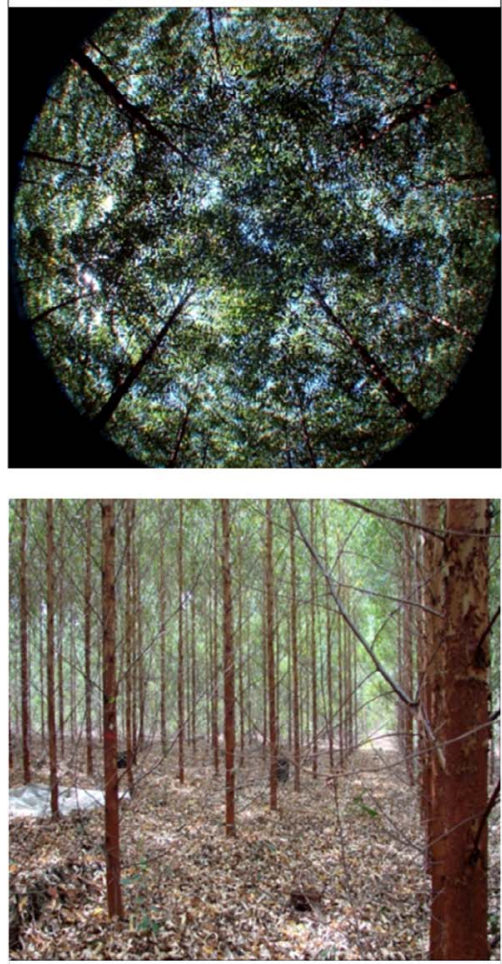

Stem production: $34 \mathrm{Mgha}^{-1} \mathrm{yr}^{-1}$

Clone C3: Site 22

Leaf area index: $3.0 \mathrm{~m}^{2} \mathrm{~m}^{-2}$
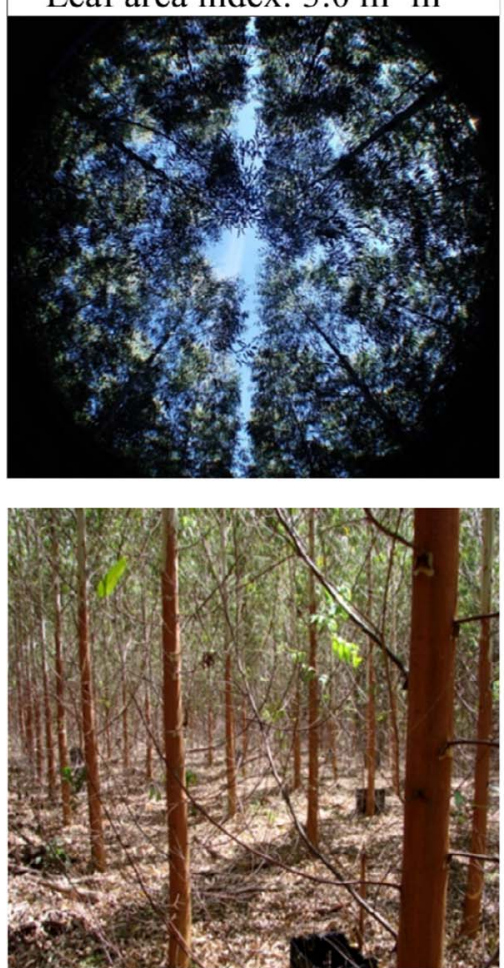

Stem production: $46 \mathrm{Mg} \mathrm{ha}^{-1} \mathrm{yr}^{-1}$
Site 20

$3.2 \mathrm{~m}^{2} \mathrm{~m}^{-2}$
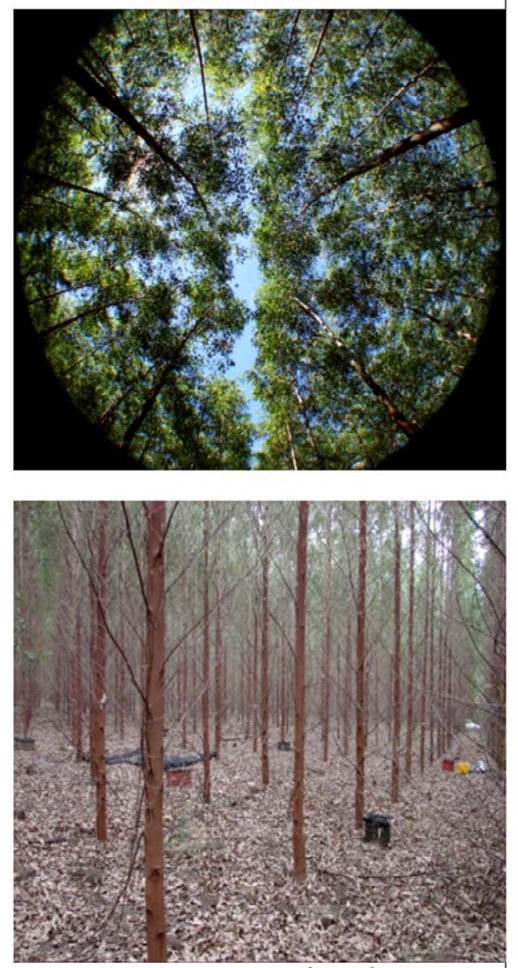

$19 \mathrm{Mg} \mathrm{ha}^{-1} \mathrm{yr}^{-1}$

Site 20
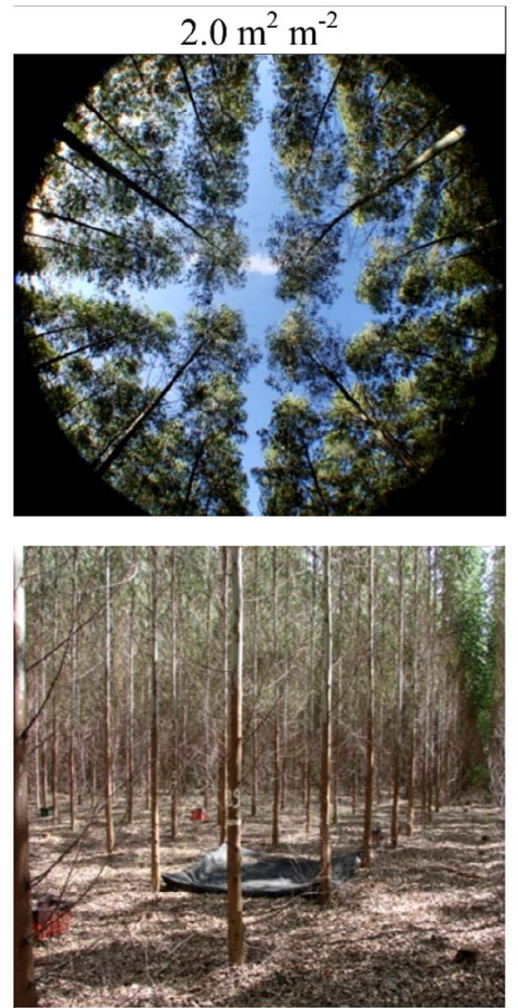

$12 \mathrm{Mg} \mathrm{ha}^{-1} \mathrm{yr}^{-1}$
Site 30

$3.5 \mathrm{~m}^{2} \mathrm{~m}^{-2}$
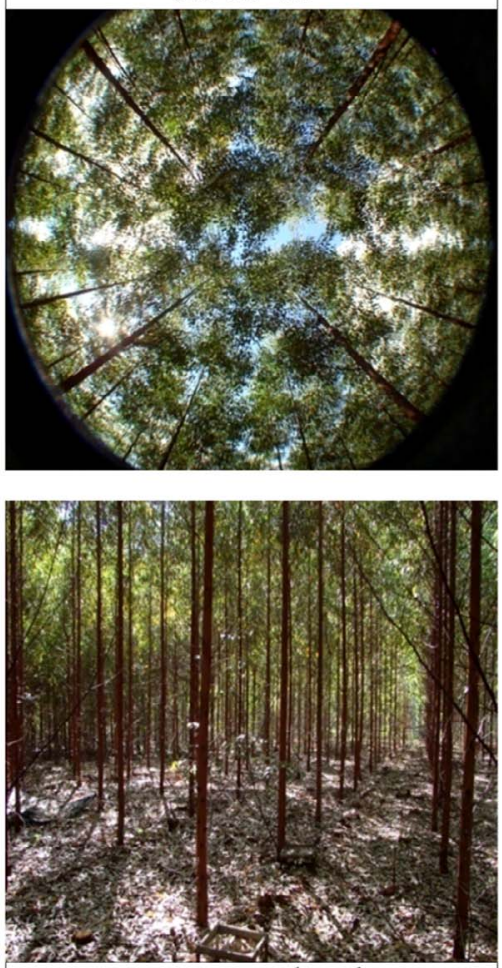

$22 \mathrm{Mg} \mathrm{ha}^{-1} \mathrm{yr}^{-1}$

Site 30
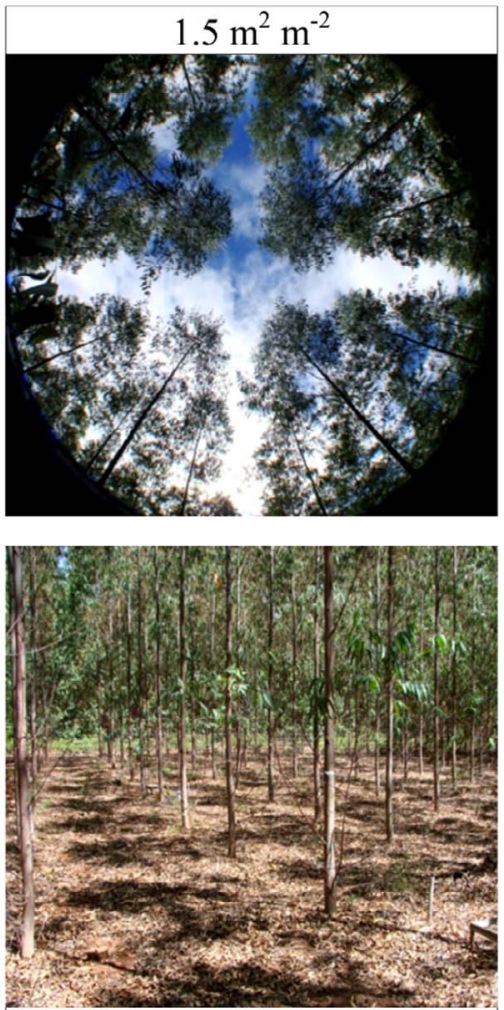

$14 \mathrm{Mg} \mathrm{ha}^{-1} \mathrm{yr}^{-1}$

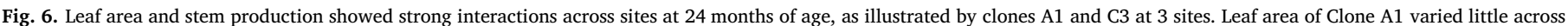
sites (upper), even though stem production differed substantially. The leaf area of Clone C3 changed more strongly across sites, in concert with stem production (bottom). 


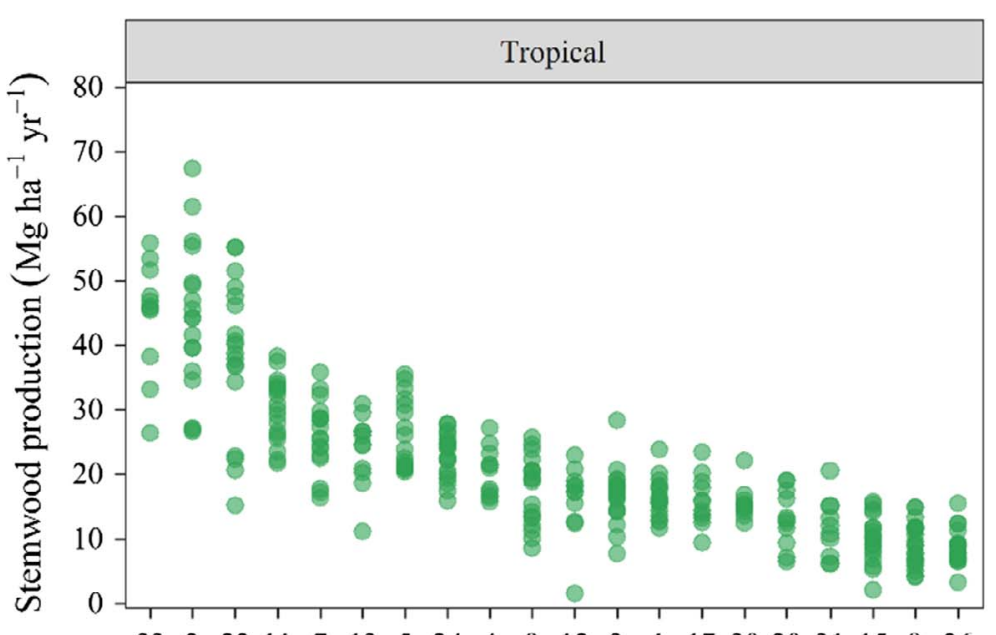

$\begin{array}{llllllllllllllllllll}33 & 2 & 22 & 11 & 7 & 13 & 5 & 24 & 4 & 9 & 12 & 3 & 1 & 17 & 30 & 20 & 31 & 15 & 8 & 26\end{array}$

Site

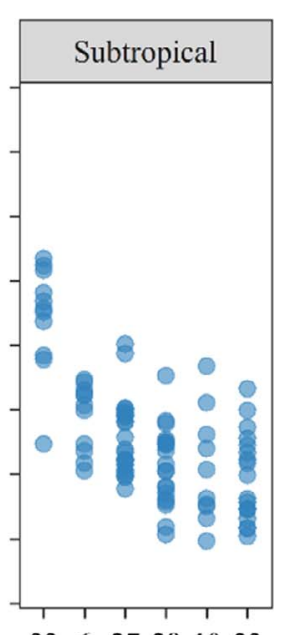

$\begin{array}{llllll}33 & 6 & 27 & 28 & 10 & 23\end{array}$
Fig. 7. The stem production varied by more than $50 \%$ among clones within sites, for both Tropical and Subtropical regions (each circle represents one clone in each site). The average production varied by about 5 -fold across Tropical sites, in contrast to a 2-fold range among Subtropical sites. Sites are sorted by decreasing productivity.
Clones planted in single region

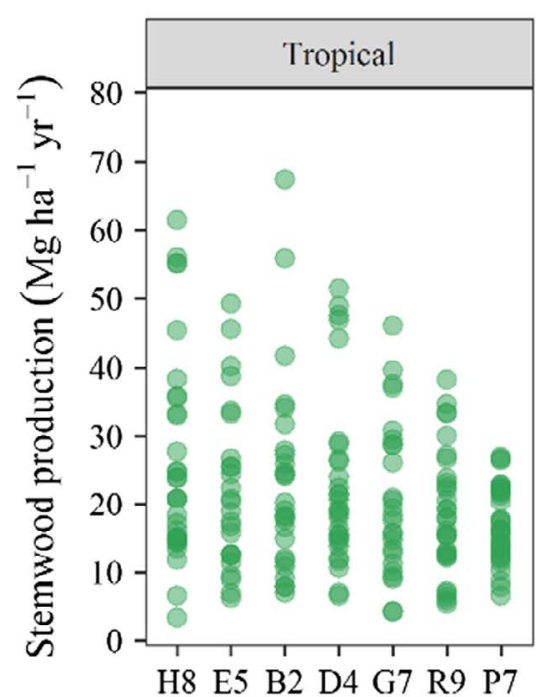

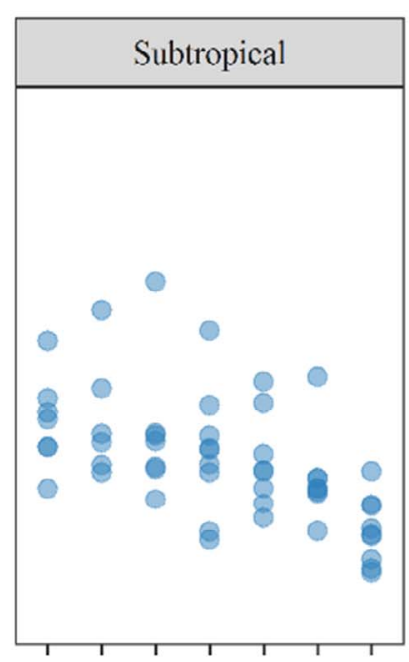

J1 O6 I9 N5 F6 M4 L3
Clones planted in both regions

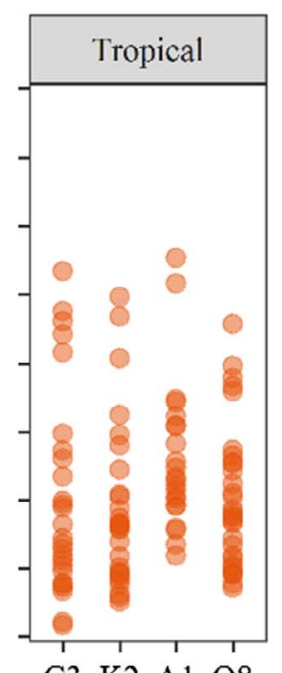

C3 K2 A1 Q8

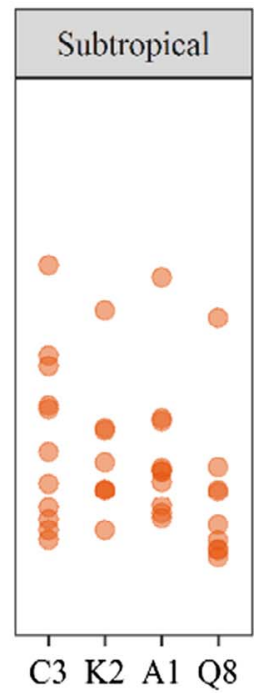

\section{Clones}

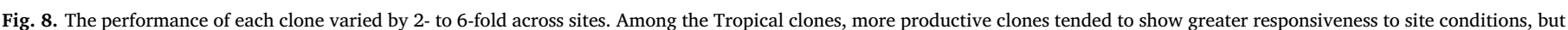

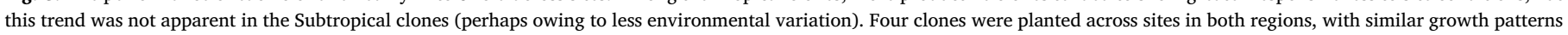
between regions.

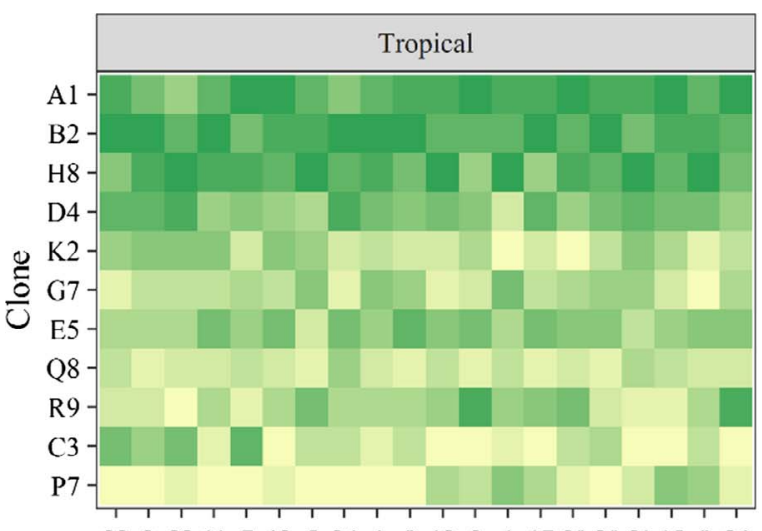

33222117135244912311730203115826 Sites

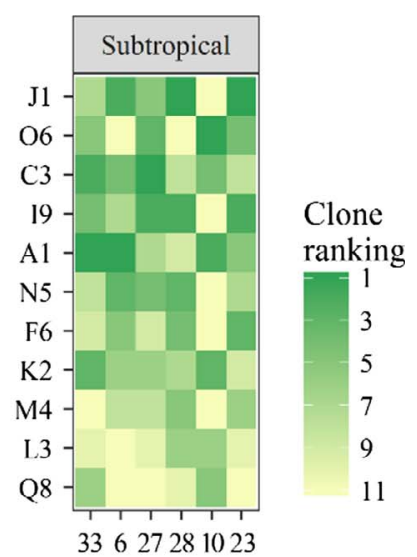

Fig. 9. Some clones, such as A1, were among the top performers across a broad range of sites, whereas others were top performers only in a few sites. Clones (from top to bottom) and sites (from left to right) are sorted by increasing productivity.

Clone

ranking

5

11 

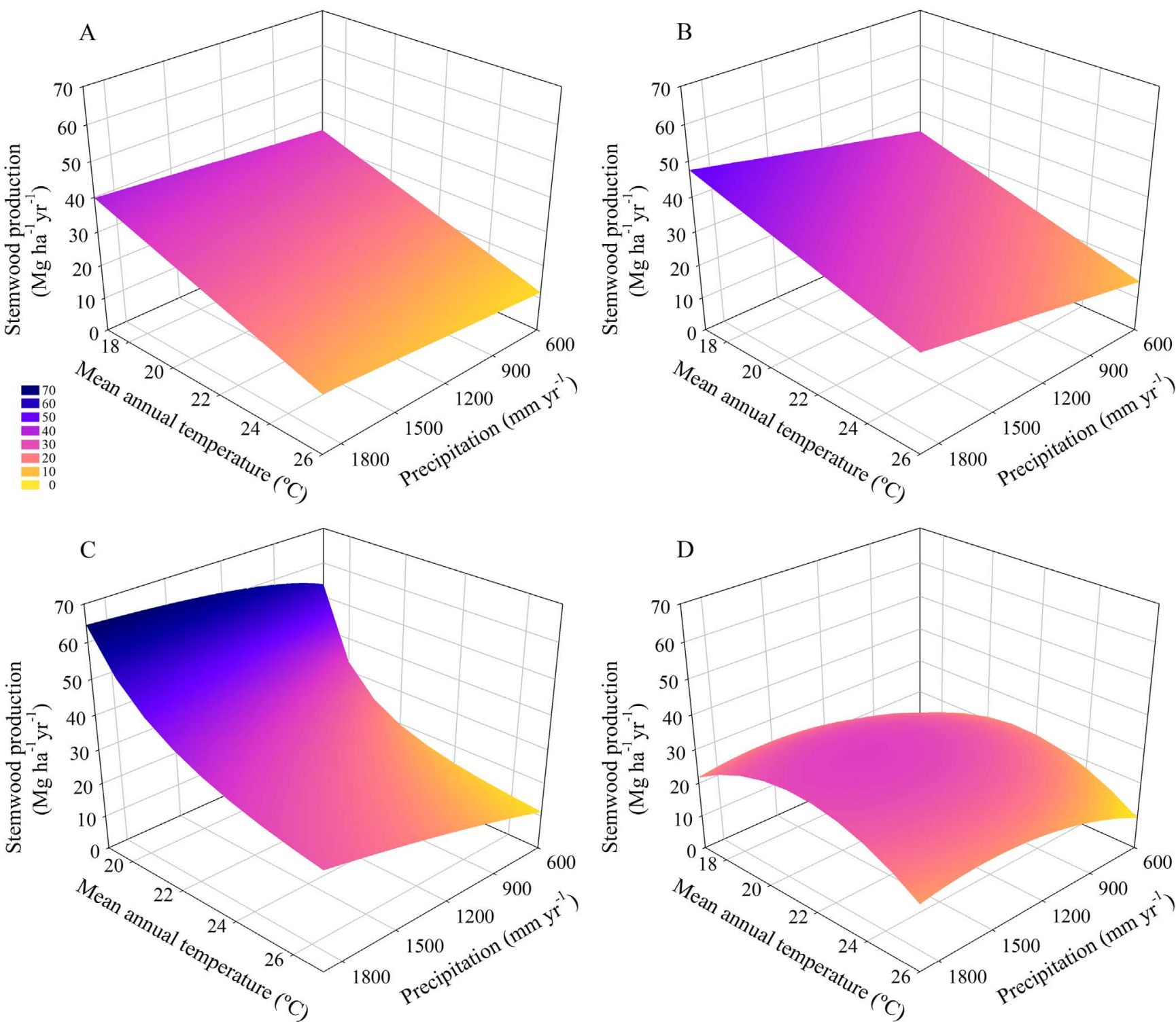

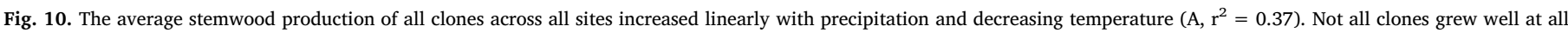

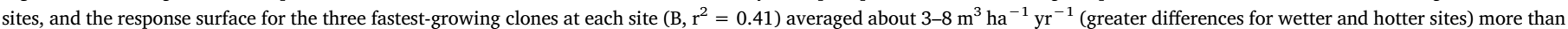

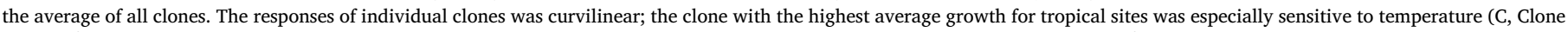
$\mathrm{D} 4 \mathrm{~B} 2, \mathrm{r}^{2}=0.70$ ), whereas the best plastic clone showed a broad optimum for both temperature and precipitation. (D, Clone A1, $\left.\mathrm{r}^{2}=0.29\right)$.

sensitivity to environmental factors, which is fundamental for selection of clones for operational planting, and parameterizing process-based models.

Finally, these results have value for understanding how the future supply of wood from intensively managed plantations of Eucalyptus would likely shift in response to changing management and climate. For example, changes in land value for growing Eucalyptus and other potential crops may shift the geography of land available for Eucalyptus silviculture. The TECHS Project results indicate that a shift to slightly warmer sites might lead to as great a reduction in growth as a shift to slightly drier sites. Changes in future climates within sites may alter both temperature and precipitation, and again changes in temperature appear to have strong potential to lower Eucalyptus production, especially for dryer landscapes. These tentative conclusions may be revised after results are available for the full rotation and the within-site water removal treatments. A full evaluation of the herbivory associated with exotic pests and diseases will also be important. The breadth of available genes and genotypes in future breeding programs may also shift this balance between the sensitivity of intensively managed plantations of Eucalyptus to temperature and precipitation.

\section{Acknowledgements}

The TECHS Project depended on the contributions of more than 150 
A

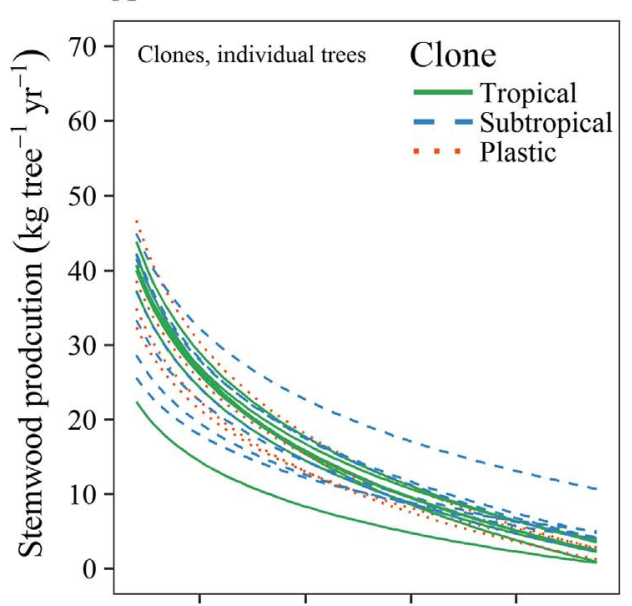

$\mathrm{C}$

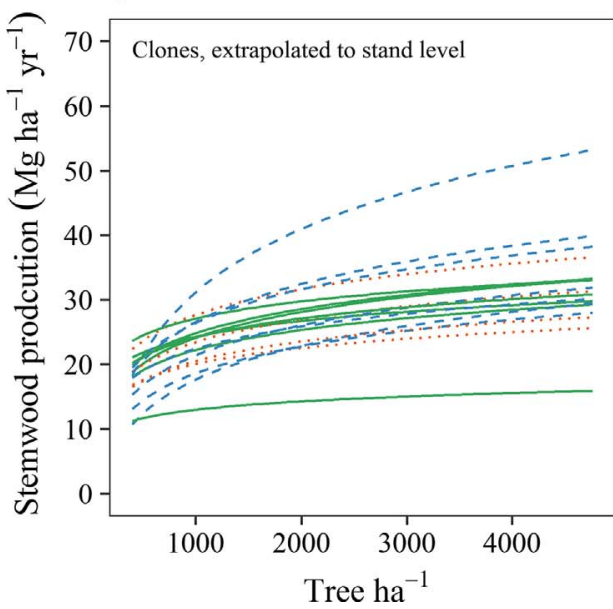

B

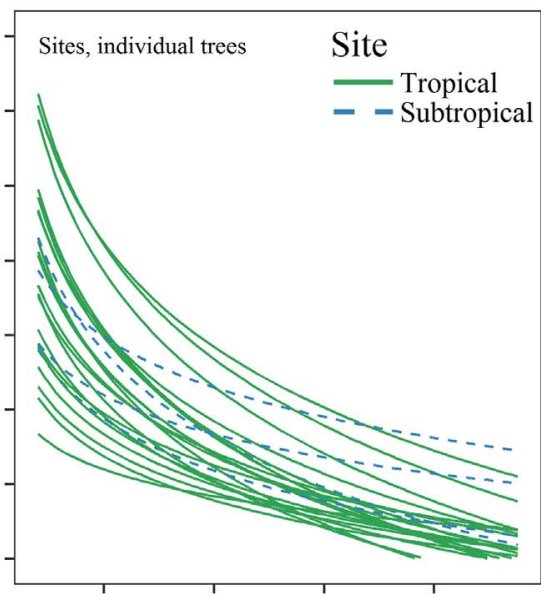

$\mathrm{D}$

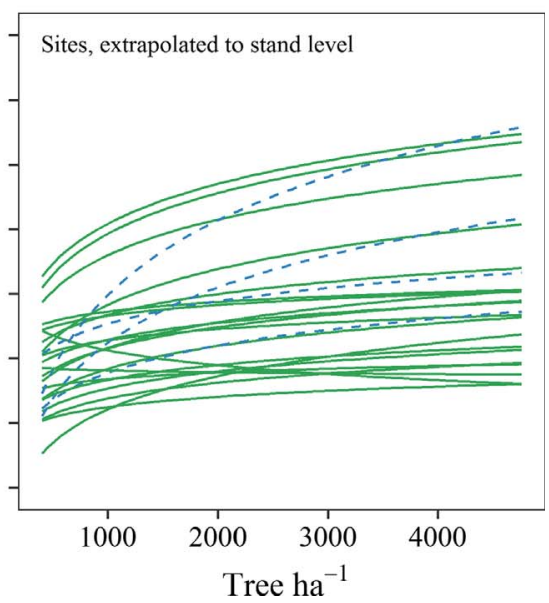

Fig. 11. The production of individual trees declined with increasing density of trees per hectare, when examined as clones across sites (A), and averages of all clones within sites (B). Extrapolation to a plot level showed that faster growing clones showed a stronger increase in relation to density (steeper slopes in C). Plot-level extrapolation of production across all clones generally showed increasing production with density, with stronger responses for subtropical sites (D).

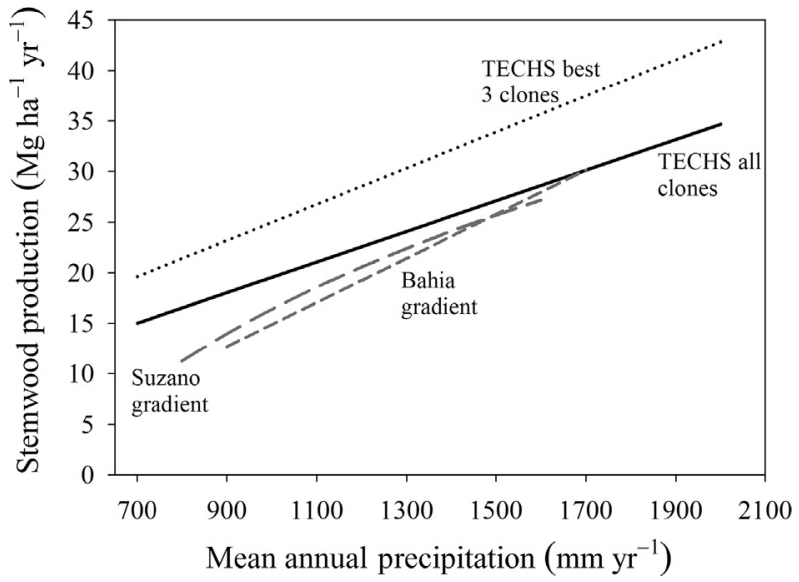

Fig. 12. The pattern of stemwood production with precipitation was similar to the pattern across a geographic gradient of 14 sites in northern Bahia (Stape et al., 2004) and across hundreds of inventory plots in southern Bahia, eastern Minas Gerais, and northern Esprito Santo (J.L. Stape, unpublished data). The TECHS lines are for the year of peak production of the rotation, and the others are lower because they are mean annual production for the entire rotation. people from 26 companies, and we thank them all for their contributions to the Project. The project was funded by the following 26 companies, with a main researcher: Anglo American (Andre Machado), Arauco (Rodrigo Coutinho), Arborgen (Gabriela Bassa), ArcelorMittal (Roosevelt Almado), Cenibra (Fernando Leite), CMPC (Elias Araujo), Comigo (Ubirajara Oliveira), Copener (jacyr Alves), Duratex (Raul Chaves), Eldorado (Vinicius Silva), Fazenda Campo Bom (Jacqueline Pirez), Fibria (Rodolfo Loos), Florestal Itaquari (Admir Mora), Forestal Oriental (Ricardo Methol), Gerdau (Francisco Gomes), GMR (Paulo Leite), International Paper (Cristiane Lemos), Jari (Katia Silva), Klabin (James Stahl), Lwarcel (Marcela Capoani), Montes del Plata (Alejandro Gonzalez), Plantar (David Fernandes), Rigesa (Ricardo Paim), Suzano (Luiz Fabiano), Vallourec (Helder Andrade) and Veracel (Helton Lourenço). Fundamental assistance was provided for many aspects of the project by Luiz Barrichelo, Dario Grattaplagia, Mike Ryan, Eduardo Mattos, Robert Hubbard, Rodrigo Hakamada, Aurelio Aguiar, Leandro de Siqueira, Gleison dos Santos and João Flavio Silva. The project also received support from these universities and institutes: University of Sao Paulo - Brazil, Sao Paulo State University - Brazil, Federal University of Lavras - Brazil, Federal University of Rio Grande do Norte - Brazil, Colorado State University - USA, North Carolina State University - USA, USDA Forest Service, CNPq - Brazil and Fapesp Brazil. 


\section{References}

Almeida, A.C., Siggins, A., Batista, T.R., Fonseca, S., Loos, R., 2010. Mapping the effect of spatial and temporal variation in climate and soils on Eucalyptus plantation production with 3-PG, a process-based growth model. For. Ecol. Manage. 259, 1730-1740.

Alvares, C.A., Stape, J.L., Sentelhas, P.C., Gonçalves, J.L.M., 2013a. Modeling monthly mean air temperature for Brazil. Theoret. Appl. Climatol. 113, 407-427.

Alvares, C.A., Stape, J.L., Sentelhas, P.C., Gonçalves, J.L.M., 2013b. Köppen's climate classification map for Brazil. Meteorol. Z. 22, 711-728.

Aspinwall, M.J., Drake, J.E., Campany, C., Vårhammar, A., Ghannoum, O., Tissue, D.T., Reich, P.B., Tjoelker, M.G., 2016. Convergent acclimation of leaf photosynthesis and respiration to prevailing ambient temperatures under current and warmer climates in Eucalyptus tereticornis. New Phytol. 212, 354-367.

Beer, C., Reichstein, M., Tomelleri, E., Ciais, P., Jung, M., Carvalhais, N., Rödenbeck, C., Arain, M.A., Baldocchi, D., Bonan, G.B., Bondeau, A., Cescatti, A., Lasslop, G., Lindroth, A., Lomas, M., Luyssaert, S., Margolis, H., Oleson, K.W., Roupsard, O., Veenendaal, E., Viovy, N., Williams, C., Woodward, I., Papale, D., 2010. Terrestrial gross carbon dioxide uptake: global distribution and covariation with climate. Science 329, 824-837.

Binkley, D., Ryan, M.G., Stape, J.L., Barnard, H., Fownes, J., 2002. Age-related decline in forest ecosystem growth: an individual-tree, stand-structure hypothesis. Ecosystems $5,58-67$.

Blackman, C.J., Aspinwall, M.J., Tissue, D.T., Rymer, P.D., 2017. Genetic adaptation and phenotypic plasticity contribute to greater leaf hydraulic tolerance in response to drought in warmer climates. Tree Physiol. 37, 83-592.

Campbell, G.S., 1986. Extinction coefficients for radiation in plant canopies calculated using an ellipsoidal inclination angle distribution. Agric. For. Meteorol. 36, 317-321.

Christina, M., Le Maire, G., Battie-Laclau, P., Nouvellon, Y., Bouillet, J.-P., Jourdan, C. Gonçalves, J.L.M., Laclau, J.P., 2015. Measured and modeled interactive effects of potassium deficiency and water deficit on gross primary productivity and light-use efficiency in Eucalyptus grandis plantations. Glob. Change Biol. http://dx.doi.org/10. 1111/gcb.12817.

EMBRAPA, 1997. Manual de Métodos de Análise de Solo. Rio de Janeiro, Brazil, EMBRAPA, pp. 212.

Faria, D.A.F., Mamani, E.M.C., Pappas Jr, G.J., Grattapaglia, D., 2011. Genotyping systems for Eucalyptus based on tetra-, penta-, and hexanucleotide repeat EST microsatellites and their use for individual fingerprinting and assignment tests. Tree Genet. Genom. 7, 63-77.

Flores, T.B., Alvares, C.A., Souza, V.C., Stape, J.L., 2016. Eucalyptus no Brasil: zoneamento climático e guia para identificação. IPEF, Piracicaba, pp. 448p.

Gonçalves, J.L.M., Alvares, C.A., Higa, A.R., Silva, L.D., Alfenas, A.C., Stahl, J., Ferraz, S.F.B., Lima, W.P., Brancalion, P.H.S., Hubner, A., Bouillet, J.P., Laclau, J.-P., Nouvellon, Y., Epron, D., 2013. Integrating genetic and silvicultural strategies to minimize abiotic and biotic constraints in Brazilian eucalypt plantations. For. Ecol. Manage. 301, 6-27.

Hakamada, R,, Hubbard, R.M., Ferraz, S., Stape, J.L., Lemos, C., 2017. Biomass produc tion and potential water stress increase with planting density in four highly productive clonal Eucalyptus genotypes. South. For.: J. For. Sci. 10.2989/20702620 2016.1256041

Hubbard, R., Stape, J.L., Ryan, M.G., Almeida, A.C., Rojas, J., 2010. Effects of irrigation on water use and water use efficiency in two fast growing Eucalyptus plantations. For. Ecol. Manage. 259, 1714-1721.

IBA, 2015. Brazilian Tree Industry Annual Report. Indústria Brasileira de Árvores Brasília.

INDUFOR, 2012. Strategic review on the future of forest plantations, report prepared for the Forest Stewardship Council (A12-06869 ID 11914) INDUFOR, Helsinki, Finland. $<$ https://www.google.com/url?sa $=$ t\&rct $=j \& q=\&$ esrc $=s \&$ source $=$ web\&cd $=1 \&$ ved $=$ 0ahUKEwiBxJPH5YbWAhVLxlQKHRtoBRAQFggoMAA\&url $=$ http $\% 3 A \% 2 F$ \%2Fwww.fao.org\%2Fforestry\%2F42701-090e8a9fd4969cb334b2ae7957d7b1505 pdf\&usg = AFOjCNGLx6aubRsbwLjgCO1i9aZ4pqF1nw > .

Laclau, J.P., 2016. Sustainable biomass production in eucalypt plantations under climate changes: insights from a throughfall exclusion experiment. In: IUFRO Regional Congress for Asia and Oceania 2016: Forests for sustainable development the role of research. IUFRO. Beijing, IUFRO, p. 42.

Lieth, H., Whittaker, R.H. (Eds.), 1975. Primary Productivity of the Biosphere. SpringerVerlag, New York

Mahecha, M.D., Reichstein, M., Carvalhais, N., Lasslop, G., Lange, H., Seneviratne, S.I., Vargas, R., Ammann, C., Arain, M.A., Cescatti, A., 2010. Global convergence in the temperature sensitivity of respiration at ecosystem level. Science 329, 838-842.

Marcatti, G.E., Resende, R.T., Resende, M.D.V., Ribeiro, C.A.A.S., dos Santos, A.R., da
Cruz, J.P., Leite, H.G., 2017. GIS-based approach applied to optimizing recommendations of Eucalyptus genotypes. For. Ecol. Manage. 392, 144-153.

Mattos EM (2015) Seasonal characterization of wood growth, canopy structure and light use efficiency in Eucalyptus clones. MSc Dissertation, University of Sao Paulo, Piracicaba, 128 pp. 10.11606/D.11.2015.tde-20102015-164358.

Norman, J.M., Jarvis, P.G., 1975. Photosynthesis in Sitka spruce (Picea Sitchensis (Bong) Carr.). Radiation penetration and a test case. J. Appl. Ecol. 12, 839-878.

Payn, T., Carnus, J.-M., Freer-Smith, P., Kimberley, M., Kollert, W., Liu, S., Orazio, C., Rodriguez, L., Silva, L.N., Wingfield, M.J., 2015. Changes in planted forests and future global implications. For. Ecol. Manage. 352, 57-67.

Core Team, R., 2014. R: A language and environment for statistical computing. R Foundation for Statistical Computing, Vienna, Austria http://www.R-project.org/.

Resende, M.D.V., Resende, M.F.R., Sansaloni, C.P., Petroli, C.D., Missiaggia, A.A., Aguiar, A.M., Abad, J.M., Takahashi, E.K., Rosado, A.M., Faria, D.A., Pappas, G.J., Kilian, A., Grattapaglia, D., 2012. Genomic selection for growth and wood quality in Eucalyptus : capturing the missing heritability and accelerating breeding for complex traits in forest trees. New Phytol. 194, 116-128.

Roy, J., Saugier, B., Mooney, H.A., 2001. Terrestrial Global Productivity. Academic Press, San Diego.

Ryan, M.G., Stape, J.L., Binkley, D., Fonseca, S., Loos, R., Takahashi, E.N., Silva, C.R., Silva, S., Hakamada, R., Ferreira, J.M., Lima, A.M., Gava, J.L., Leita, F.P., Silva, G., Andrade, H., Alves, J.M., 2010. Factors controlling Eucalyptus productivity: How resource availability and stand structure alter production and carbon allocation. For. Ecol. Manage. 259, 1695-1703.

Schumacher, F.X., Hall, F.S., 1933. Logarithmic expression of timber volume. J. Agric Res. 47, 719-734.

Scolforo, H.F., Scolforo, J.R.S., Stape, J.L., McTague, J.P., Burkhart, H., McCarter, J., Neto, Fd.C., Loos, R.A., Sartorio, R.C., 2017. Incorporating rainfall data to better plan Eucalyptus clones deployment in eastern Brazil. For. Ecol. Manage. 391, 145-153.

Silva-Junior, O.B., Faria, D.A., Grattapaglia, D., 2015. A flexible multi-species genomewide $60 \mathrm{~K}$ SNP chip developed from pooled resequencing of 240 Eucalyptus tree genomes across 12 species. New Phytol. 206, 1527-1540.

Soil Survey Staff, 1999. Soil Taxonomy: A Basic System of Soil Classification for Making and Interpreting Soil Surveys. United States Department of Agriculture, Natural Resources Conservation Service, Agriculture Handbook Number 436. Washington, DC. $886 \mathrm{p}$.

Stape, J.L., Binkley, D., Ryan, M.G., 2004. Eucalyptus production and the supply, use and the efficiency of use of water, light and nitrogen across a geographic gradient in Brazil. For. Ecol. Manage. 193, 17-31.

Stape, J.L., Binkley, D., Ryan, M.G., 2008. Production and carbon allocation in a clonal Eucalyptus plantation with water and nutrient manipulations. For. Ecol. Manage. 255, 920-930.

Stape, J.L., Binkley, D., Ryan, M.G., Fonseca, S., Loos, R., Takahashi, E.N., Silva, C.R., Silva, S., Hakamada, R., Ferreira, J.M., Lima, A.M., Gava, J.L., Leite, F.P., Silva, G., Andrade, H., Alves, J.M., 2010. The Brazil Eucalyptus Potential Productivity Project: influence of water, nutrients and stand uniformity on wood production. For. Ecol. Manage. 259, 1686-1694.

Sutton, W.R.J., 2014. Save the forests: use more wood. In: Fenning, T. (Eds.), Challenges and opportunities for the world's forests in the 21st century,, Springer, New York. 10. 1007/978-94-007-7076-8_9.

Thornthwaite, C.W., Mather, J.R., 1957. Instructions and tables for computing potential evapotranspiration and the water balance. Publication in Climatology 10(3), Drexel Institute of Technology, Laboratory of Climatology, Centerton, N.J.

van Raij, B., Andrade, J.C., Cantarella, H., Quaggio, J.A., 2001. Análise química para avaliação da fertilidade de solos tropicais. Instituto Agronômico de Campinas, Campinas, pp. 285.

Wang, W.M., Li, Z.L., Su, H.B., 2007. Comparison of leaf angle distribution functions: Effects on extinction coefficient and fraction of sunlit foliage. Agric. For. Meteorol. $143,106-122$.

Whiteman, A., 2014. Global trends and outlook for forest resources. In: Fenning, T. (Ed.), Challenges and opportunities for the world's forests in the 21st century, Springer, New York. 10.1007/978-94-007-7076-8_8.

Willmott, C.J., Matsuura, K., 2005. Advantages of the mean absolute error (MAE) over the root mean square error (RMSE) in assessing average model performances. Clim. Res. $30,79-82$.

Wingfield, M.J., Roux, J., Slippers, B., Hurley, B.P., Garnas, J., Myburg, A.A., Wingfield, B.D., 2013. Established and new technologies reduce increasing pest and pathogen threats to Eucalypt plantations. For. Ecol. Manage. 301, 35-42. 